Historic, Archive Document

Do not assume content reflects current scientific knowledge, policies, or practices. 



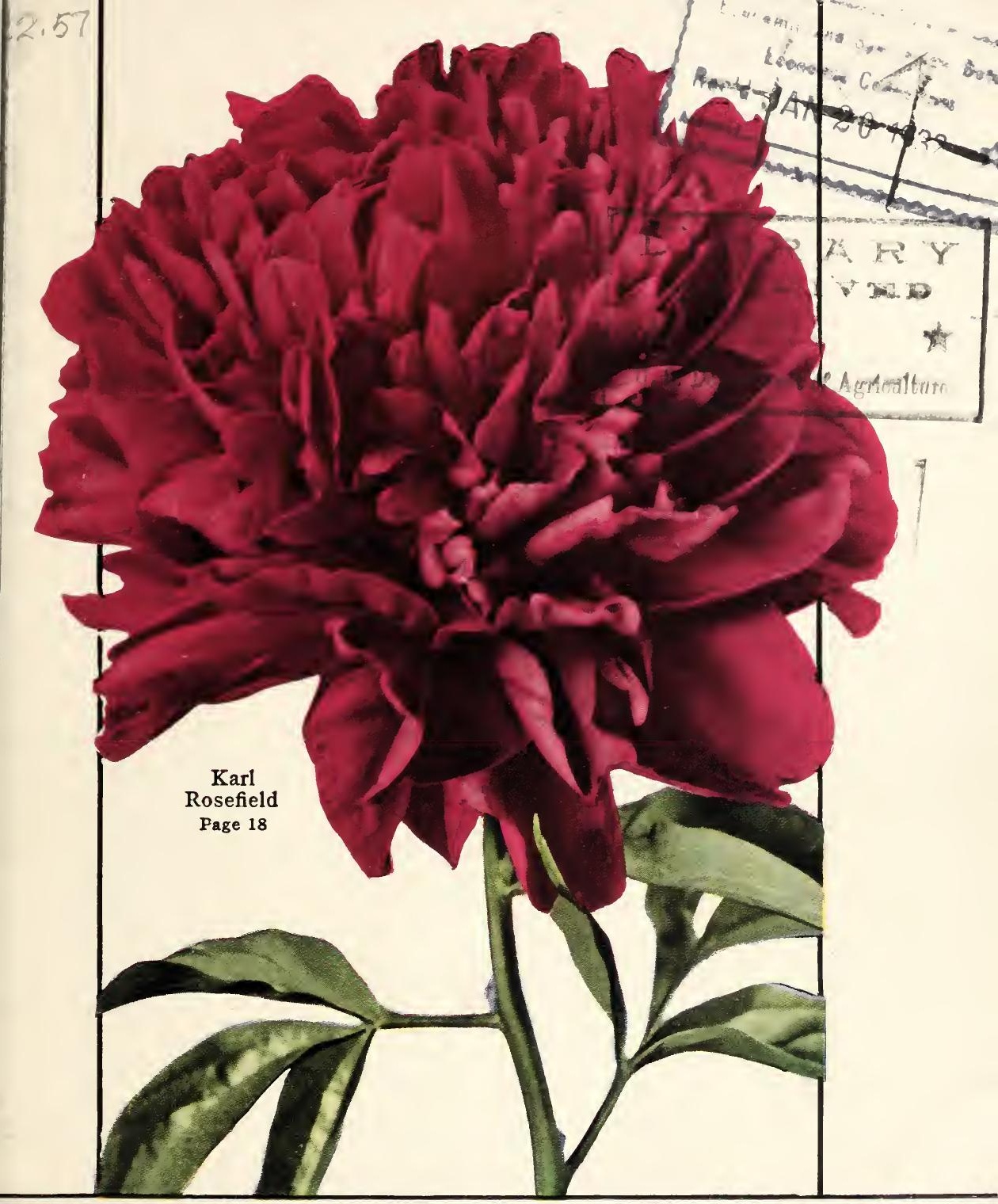

\section{The FlowerBeautiful}

1931 


\section{Special \\ Announcement}

\section{Peony Shipping Season}

- . T Thansportation charges will be prepaid on all retail Peony orders, paid for in advance, that are to be shipped east of the Mississippi. To obtain prepaid shipment west of the Mississippi, the order must amount to $\$ 10.00$ or more, paid in advance.

We will ship either by Express or Parcel Post, depending upon the size of the order. If your Express Office is different from your Post Office, please state this on the order sheet.

\section{on}

\section{"A Little Book About Roses"}

The above is the title of our rose catalog published annually in September. In many localities, autumn planting is favored by professional and amateur rosarians. Two-year, field-grown plants, hardened and wellripened, are dug and shipped from October 15 until December 1. In spring, plant as early as possible.

You will find this rose booklet both belpful and inspiring. It is sent free to our patrons and intending purchasers. 


\section{By Way of}

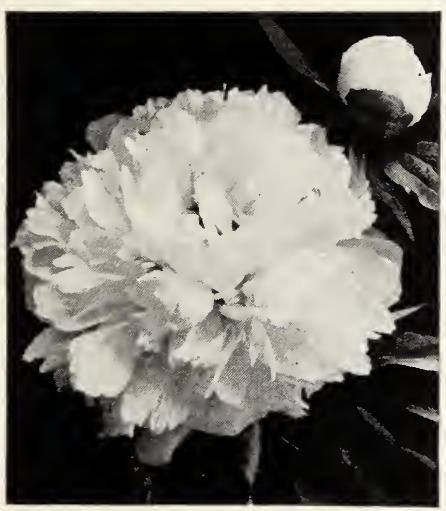

NEVER was there a time in recent years when the Peony, "King" of hardy perennial flowers, was more worthy of the title. Peonies everywhere are so exceptionally well-flowered, and their ability to "come through" triumphantly, after several most trying and adverse seasons, has undoubtedly instilled in the hearts of all of us a greater affection for this loyal flower.

In our own fields, and in the exhibition beds, the color, size, and delicacy of blooms were appreciated to an extraordinary degree by hundreds of true flower Iovers who are making it a habit to come every year. Here, amidst pleasant and convenient surroundings, you are all invited to enjoy and study the modern Peonies as we grow them.

To the amateur gardener who is just beginning to grow Peonies, may we call your attention to the fact that our constant aim is to produce and seIl a matured plant that will flower the first year. The plants now maturing in ages from one to three years, all growing on the new farm in soil virgin to Peonies, will develop into ideal size roots for digging and shipping this fall. The Peony is easy to grow, provided you begin with healthy, undivided roots and plant them in an open, sunny location in just an average garden loam.

This business has been through many ups and downs in its nearly thirty years of existence and we know it is impossible for us to grow quality roots up to the same high standard, and continue to give the same service and advice as we have in the past, unless we get a fair return for our product. Where the supply warrants it, we have cheerfully passed on the saving to our prospective customers. And the fact that we are going to prepay transportation charges on most shipments this fall (1931) will make your doIlars go considerably farther.

To the many Peony enthusiasts who have been Ioyal supporters of this business since its foundation we want to say "Thank you" with more sincerity than ever. Both old and new patrons will find that the Peony stock for 1931, together with a prompt and most courteous service, will please the most exacting buyer.

June 20, 1931 . 


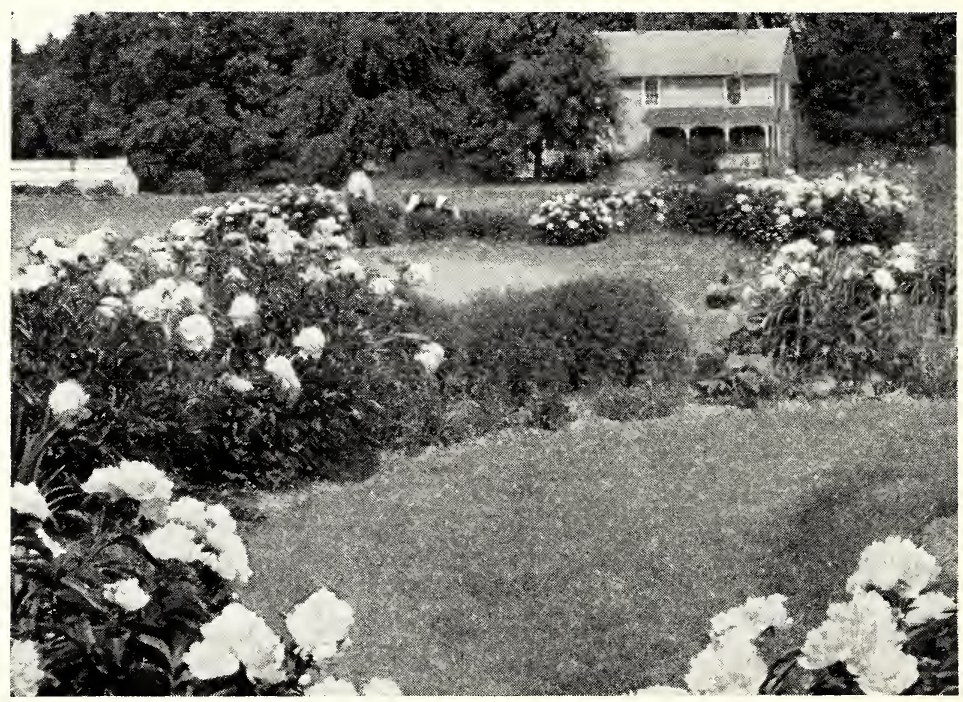

\section{A Few Timely Remarks to the Prospective Buyer}

$\mathrm{F}$

IRST of aII, there is no plant that will stand the vicissitudes of winter, even in the coldest climates, better than the Peony-aII varieties are equally hardy. We have tried to make the selection of Peonies comparatively simple by, year after year, discarding undesirable ones which are replaced by newer and better kinds. For the beginner, the collections on pages 28 and 29 may be depended upon to give a wide range of color and long season of bloom.

Just why some varieties are so much higher in price than others is confusing to many who are not yet real Peony fans or hobbyists. Certain kinds propagate very slowly, and in the newer introductions the demand is always greater than the supply, consequently, prices remain higher. But let it be pointedly stated that a high price does not necessarily mean that a variety is better in color, shape, or substance of petalage; many of our Iower- and medium-priced varieties, in good supply, possess qualities of refinement hardly surpassed by our newer ones costing considerably more.

Were we to put ourselves in place of the prospective buyer of Peonies, the appeal of so many growers would be just cause for bewilderment. Looking back more than a quarter of a century ago, when this business was founded, the number of reliable growers of national reputation could be counted on one hand. Today, growers and dealers as weIl exist in much greater numbers, testifying, of course, to the increased popularity of this noble flower. Very few, however, seek your patronage on the same basis we do. May the quality and contents of this catalog represent to you the quality of the business it represents. Pages 36 and 37 teIl you better than we could of the high quality of the roots you will invariably receive. 


\section{George H. Peterson, Inc., Fair Lawn, ․ J.}

Many of our patrons within motoring distance have enjoyed visiting the exhibition-gardens this season. Garden clubs from towns in northern New Jersey have profited by their visits in a body, when one of our organization is always present to welcome them and answer questions. Visitors are not piloted through Iong, dusty nursery rows but will find sample plants of all the varieties we offer growing in narrow beds separated by wide grass walks. Every variety is plainly labeled. Come visit us during the flowering season and make note of your favorites. See page 35.

\section{THE BEST SIZE ROOT TO PLANT}

Where one has a large Peony business, it would be following the lines of least resistance to ofler divisions only, since in the first place it would not then be necessary to annually plant out, as has always been our custom, new fields of practically every variety we offer. Then, too, the matter of booking and filling orders would be a comparatively easy task, since much correspondence would be saved in the more than busy shipping season as some size became sold out.

Many if not most planters want results in the way of bloom without waiting too long in an existence here which at best is short; and where a division is desirable if a larger root cannot be afforded, it is no less than absurd to address intelligent people with the claim that a division is to be preferred for amateur or garden planting. It is true that in cut-flower and commercial plantings these cut or divided portions of roots are to be preferred and possibly even necessary, since otherwise in the purchase of hundreds and thousands of roots the cost would be prohibitive.

The one-eyed root of a few years ago, which we ridiculed and never stooped to, has met a deserved death. This was followed by the "small" and "Iarge" division. We now hear much of the "well balanced, natural division" but very few dealers teII us from what aged roots these will be taken. Every Peony propagator well knows that the best divisions are made from roots two, and in some cases, three years old. Where the roots are older than three years, the crown or upper portion of the root solidifies more or less so that desirable general division can no Ionger be made. Where divisions are made from clean two-year roots, no general pruning further than a reasonable shortening of the roots is necessary or even desirable. Where the roots are old, decayed, or more or less diseased, then an excuse for short pruning is a good thing for some growers to fall back upon.

This division-only argument will not, we know, influence the host of customers who for a quarter of a century have made this business what it is (their continued success through the years speaks for itself), but in the hope that the novice will tahe with a grain of salt the claim of the "division only" propaganda, we will repeat here, as it appeared in our catalog the past few years, the written opinion on this matter of no less and disinterested an authority than Prof. A. P. Saunders, now Vice-President of the American Peony Society, and looked upon as an anrateur Peony authority, much as Dr. J. Horace McFarland is looked upon today in the rose world. Professor Saunders' opinion as it appeared in an issue of the Garden Magazine a few years ago follows:

"What are called one-year roots are the plants that have resulted from the divisions of last year but evidently the nurseryman can save himself money by selling the divisions at once to his customers without taking the trouble to replant and cultivate for a year. These freshly made divisions

See pages 28 and 29 for money-saving collections of Peonies 


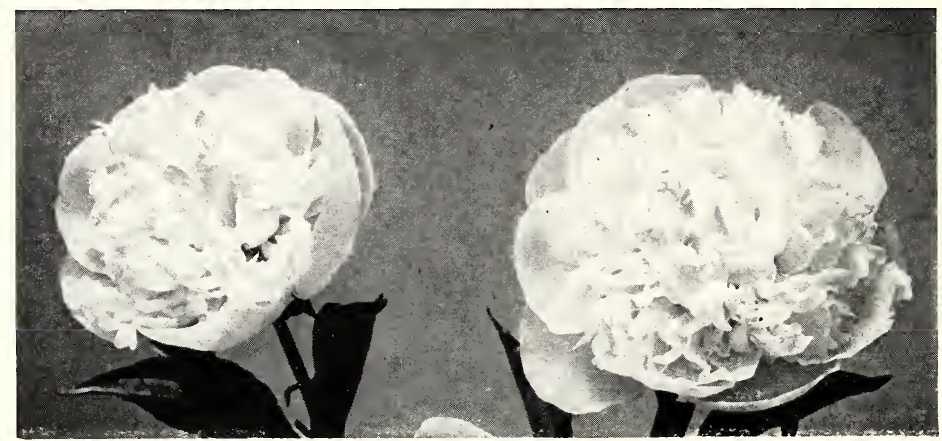

Duchesse de Nemours. See page 12

are very commonly offered in the trade and at prices much below those for one-year roots. The question is whether the purchaser is wise to take them and the subject is much debated among the growers. My own judgment on it is this: where the question of price has to be very carefully considered and the question of time is a matter of indifference, the buyer may probably do well to buy divisions of the expensive sorts. But what he saves in money he loses in time; for, whereas a one-year root will usually bloom well within two or three years after planting and will give some bloom the first year, a division cannot be expected to give good bloom for a considerably longer time. Also, the actual loss in plants is certain to be greater.

"He who is tempted by the low price on divisions may well reflect that the Peony is a slow plant at best and that the real values of time and money, when the time is reckoned in years, will bear careful thinking over."

\section{THE ROOTS WE SEND OUT}

"One-year" roots are those which have grown a full year since division. "Two-year" roots have grown two years since division, and where the cost can be borne are of course more desirable, as the immediate effect is greater.

Our "divisions" of even the rarest kinds will average 3 to 5 eyes and with rare exceptions will, if planted at the proper depth, produce bloom the first season.

That our roots invariably do so flower is attested by the hundreds of letters we receive each season from enthusiastic customers. (See pages 36 and 37.)

\section{MOST ECONOMICAL PLANT TO BUY}

While its first cost may seem high, it is really the most economical plant one can buy from the fact that it represents a permanent investment and one which pays annual dividends of increase of at least 100 per cent. Almost every family, of even the most moderate means, spends annually quite a tidy little sum in bulbs, geraniums, and other bedding plants, and at the end of the year has nothing left to show for it. Plant the Peony, and it will Iast as Iong as you do-and Ionger. Plantings may be left undisturbed from ten to twenty years, or even Innger, if the soil is occasionally enriched. 


\section{USES}

There is probably no other plant with such varied usefulness. For effective massing in landscape work the Peony is unequaled. As an edging or facing for shrubbery, it is likewise good. Planted in beds, or borders, or as specimen plants on the lawn, it is equally at home. It is particularly attractive when used to border a drive or walk.

An attractive use for the Peony is low, ornamental, Iawn hedging. This, of course, applies where only ornament, and not defense, is required. The dark, glossy green foliage, untouched by disease or insects, is exceedingly attractive through the spring and hot summer months.

And the cost, too, in some of the most desirable low-priced sorts will prove quite moderate, since the plants for this purpose may be set $21 / 2$ to 3 feet apart, and a single row is quite ample.

\section{AS A CUT-FLOWER}

It is hardly equaled. Cut as the bud is about to unfold, and placed in water in a cool room, where the air is fresh night and day, most varieties will last several days. The blooms will then be superior to those left to open on the plant and exposed to the heat of the sun.

If set at once in a cold, dark cellar the different varieties may be kept several days longer than their blooming period. Bring up as wanted.

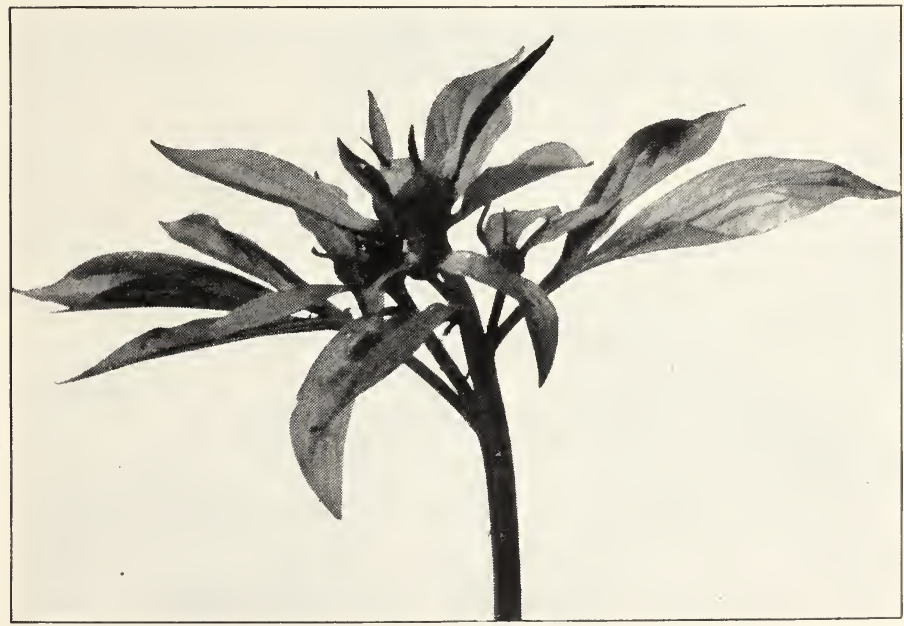

A Peony growth just after the buds are formed

\section{DISBUDDING}

Most Peonies usually set three or more buds to a stem. (See cut above.) AII but the central (largest) bud should be pinched off as soon as they can be gotten hold of if the finest individual blooms are wanted. 


\section{CUTTING BLOOMS}

When cutting flowers, always leave at least two leaf-stems on stalk cut. It is best not to cut all of the flowers, as it is of vital importance that sufficient foliage be left on the plant all summer to develop the eyes under ground for next season's growths and blooms.

\section{TRUENESS}

Desirable as it is to get fine, strong roots, it is of even greater importance that stock be true to name, and it is in this phase of the business that we especially challenge comparisons. During the blooming season our personal time is devoted almost exclusively to the study of varieties and proving stock and during the past four years not even one "rogue" or mixture has appeared in our entire plantings. The pith of all this is weIl, if briefly, expressed in this enthusiastic statement of a patron, "If you get it of Peterson, it's true."

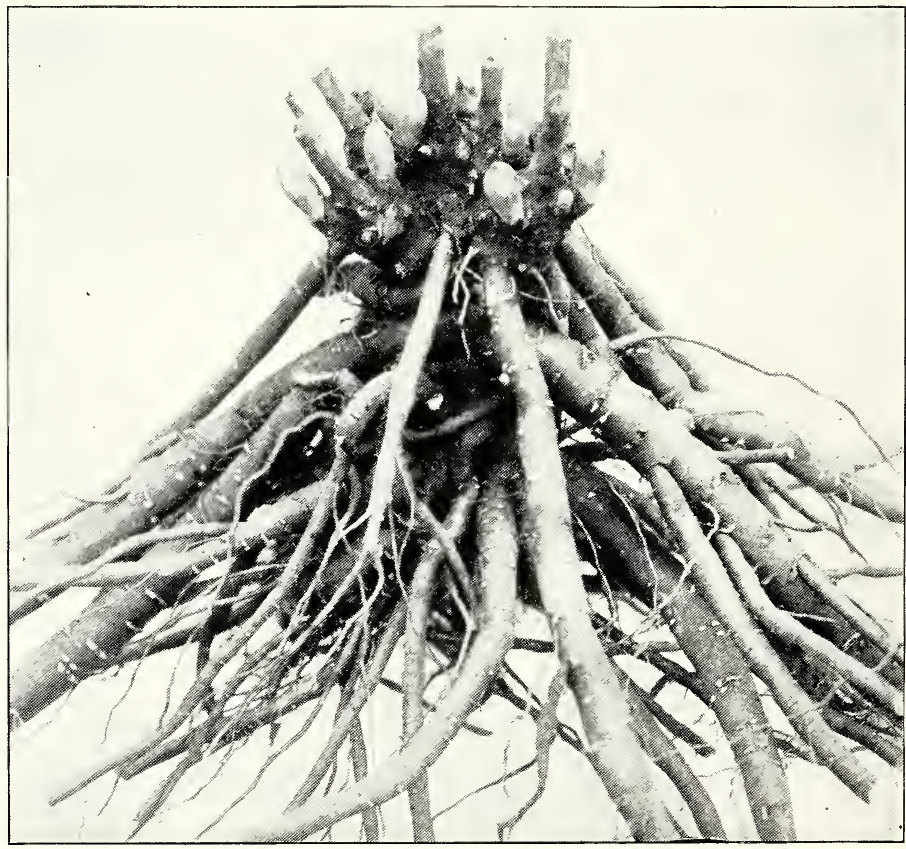

A Dormant Peony Root 


\section{HOW THE PEONY IS SENT TO YOU}

The Peony is sent out in the form of a root (see cut, page 8), from which, when dormant, will be seen protruding pinkish "eyes" or buds, the strongest of which will throw up next season's flowering shoots.

\section{WHEN SHIPMENT IS MADE}

We usually begin shipping about September 10, unless shipment is requested earlier.

We do not ship Peonies in the spring. The spring planter, since most Peonies are sold and planted in the fall, must take the leavings, no matter where he purchases, and then, too, it is almost an impossibility to dig and pack Peony roots in the spring without breakage of the brittle, tender growths. The frost is barely out of the ground ere growth begins and as this flower has only to early June to make its entire top growth for the season, a spring transplanting means a dwarfed growth which in turn cannot develop strong eyes for the following year.

FaIl is decidedly the better and natural season to plant this noble flower.

\section{CAN BE SHIPPED SAFELY ANYWHERE}

The Peony, in fall, can stand without injury a journey of months if kept from prolonged heat, which would start it into growth. There is, in fact, no flower which can be transported over long distances with greater safety.

\section{PRICES}

Are net, as quoted, except as noted below, and are as low as a like quality can anywhere be obtained. The thorough cultivation given our Peonies, going over the frelds with the cultivator and hoe every ten days the entire season, and the extreme care exercised in handling, labeling and packing, we have never seen equaled elsewhere. And remember that a Peony root, one or two years old quoted at a certain price, may actually be worth two or three of same variety sold as divisions but quoted for less money elsewhere.

\section{DISCOUNTS}

Orders a mounting to $\$ 10.00 \ldots \ldots \ldots \ldots \ldots \ldots \ldots \ldots \ldots \ldots \ldots$ off

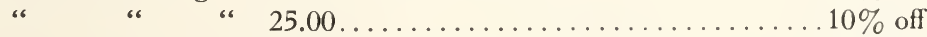

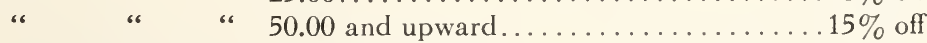

These discounts apply to all Peonies offered in this catalog except as follows:

The Collections at special prices and mixed Peonies are net.

Where rare Peonies (those costing more than $\$ 5.00$ per root) only are ordered, prices are net, but if such are ordered together with like value in standard or lower-cost kinds, the above discounts may be applied to all.

If you have any doubt as to what discount you are entitled to, send in your list and we will net price it for you. 


\section{Color Classification and Season of Bloom}

T

HE following table will save you time and make it unnecessary to go through our entire list if you are choosing varieties in certain colors that will flower at different times. Refer to index on page 38 to find the sections where these varieties are fully described and priced.

\section{WHITE \\ LIGHT, BLUSH, DEEP PINK or FLESH PINK Or ROSE \\ RED AND}

EARLY

\section{Duchesse de Nemours Festiva Maxima Madame de Verneville}

Judge Berry

Octavie Demay

Umbellata Rosea
Madame Calot

\section{Edulis Superba} General Bertrand Modeste Guerin Mons. Jules Elie Off. rosea plena Pierre Reignoux

\section{MIDSE ASON}

Boule de Neige James Kelway Jubilee La Rosiere Le Cygne Madame Emile Lemoine Marie Jacquin Mons. Dupont Nymphaa

\section{Alsace-Lorraine Avalanche Baroness Schroeder Frances Willard Kelway's Glorious Solange (Distinct.) Tourangelle}

Alfred de Musset Canari Couronne d'Or Pasteur

Asa Gray
Eugenie Verdier
Floral Treasure
Germaine Bigot
Lady Alexandra Duff

Alexandre Dumas

Duchesse d'Orleans

Madame Ducel

Madame Geissler

Lady Alexandra Duff Souv. de Louis Bigot

Lamartine (Gigantea) Walter Faxon

Mme. Barillet Deschamps

Marie Crousse

Reine Hortense

Suzanne Dessert

Therese

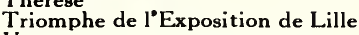

Venus

\section{LATE MIDSEASON}

\section{Edwin C. Shaw Claire Dubois}

Madame Lemonier Sarah Bernhardt

Marguerite Gerard

Mme. Jules Dessert

Raoul Dessert
Adolphe Rousseau

Cherry Hill

Off. rubra plena

Richard Carvel
Atrosanguinea Charles McKellip Felix Crousse Fontenelle

Karl Rosefield Lora Dexheimer Mons. M. Cahuzac Philippe Rivoire Victoire de la Marne
Augustin d'Hour Eugene Bigot Longfellow Madame Gaudichau
Elizabeth B. Browning Enchanteresse Marie Lemoine Mireille

TRICOLORED

Gloire de Charles Gombault. Midseason. Jeanne d'Arc. Midseason. Philomele. Midseason.

\section{Fragrant Peonies, Medium Priced}

\author{
Avalanche \\ Boule de Neige \\ Couronne d'Or \\ Duchesse de Nemours \\ Festiva Maxima
}

Gismonda

Grandiflora

La France

Pierre Duchartre

\begin{tabular}{|c|c|}
\hline & \\
\hline $\begin{array}{l}\text { Albert Crousse } \\
\text { Chestine Gowdy } \\
\text { Livingstone } \\
\text { Madame de Galhau } \\
\text { Madame Emile Galle } \\
\text { Madame Forel } \\
\text { Milton Hill } \\
\text { Modele de Perfection } \\
\text { Phoebe Cary }\end{array}$ & $\begin{array}{l}\text { Auguste Villaume } \\
\text { Louise Renault } \\
\text { Rosa Bonheur } \\
\text { Souv. de l'Exposition Universelle }\end{array}$ \\
\hline
\end{tabular}

VERY LATE

Marechal Vaillant

Rubra Superba

\section{YELLOW}

Laura Dessert

Primevere 


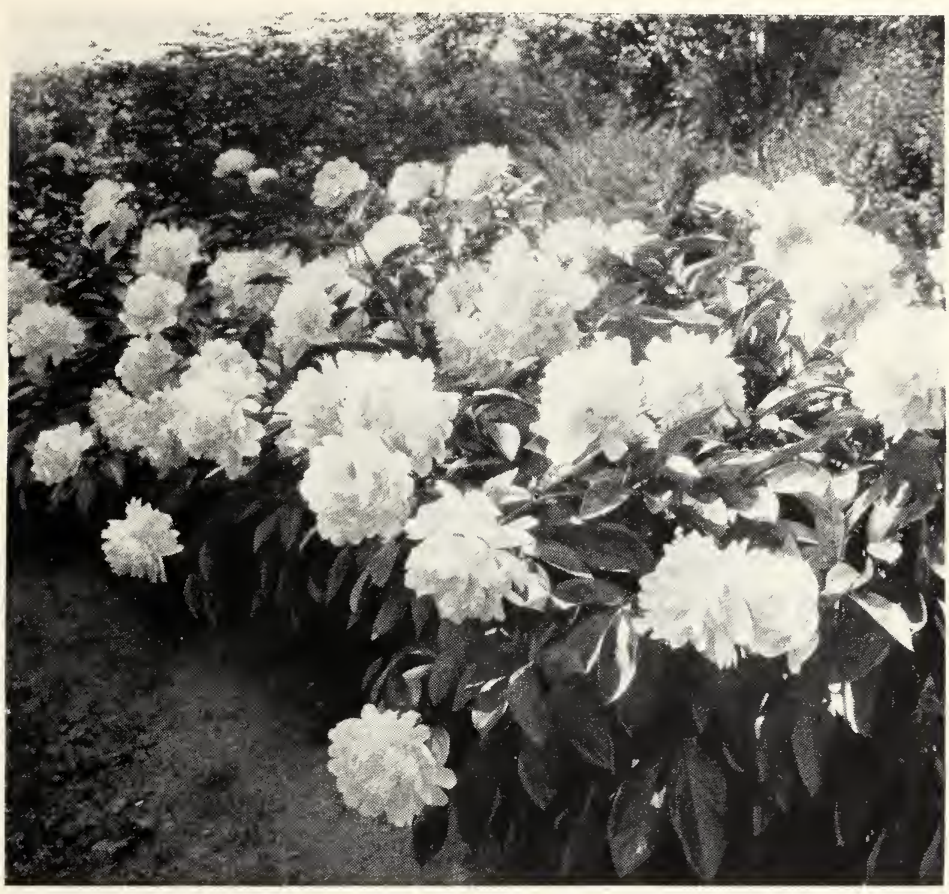

Festiva Maxima. See page 12

\section{Herbaceous Chinese Peonies}

Paeonia albiflora

\section{SECTION A}

1-year, 75 cts.; 2-year, $\$ 1.25$

Each variety can be supplied this year only in years old indicated by figures following description.

BOULE DE NEIGE. Calot. 8.0. Very Iarge, cup-shaped, suIphur-white flower with golden reflections; center petals freely bordered carmine. Buds marked and splashed carmine, as in La Tulipe. Good, strong, upright grower; stems long and stout. Fine, dark foliage. Fragrance very strong and sweet. $1-2$.

CANARI. Guerin. Outer petals flesh-white, with full yellow center. Very tall grower; sweetly fragrant. Very prolific bloomer. Splendid value for its price. $1-2$.

Undivided clumps produce many good blooms the first year and thereafter 
DUCHESSE DE NEMOURS. Calot. 8.1. Guard petals white; center lemonyellow, with greenish reflex. The flower opens at first cup-shaped, disclosing its lovely lemon-yellow center, then gradually develops into a large, well-formed full bloom which gradually fades to white. Among all Peonies there is nothing so exquisitely chaste as this variety in a halfopen state. A good, profuse, sure bloomer; sweetly fragrant. Fine habit. Splendid cut-flower. Blooms early. 1-2. Also 3-year, $\$ 1.75$.

DUCHESSE D'ORLEANS. Guerin. Large, carmine-pink guard petals, with center of soft pink, interspersed with salmon. Nice, pointed bud. Tall grower. An exceedingly good, perfect bloomer and very pretty flower. One of the most desirable of low-cost sorts. 1-2. Also 3-year, \$1.75.

EDULIS SUPERBA. Lemon. 7.6. Beautiful, brilliant rose-pink, silvery reflex; large, well-formed, full flower on good stem. Blooms very early, just before Festiva Maxima, and lasts well; fragrant and good in every way. A much worthier sort than its price would seem to indicate. There is quite a stock of it in existence. Splendid for Decoration Day. 1-2.

FESTIVA MAXIMA. Miellez. 9.3. Very large and full, pure white flower, with few center petals usually tipped with blood-red spots. A very vigorous grower, with massive foliage, flowers coming on long, stiff stems; fragrant. Early, and blooms most abundantly. Perhaps the very best all-round white we possess. Best known and most popular. Were this a new variety it would be cheap at $\$ 10.00$. 1-2. Also 3-year, $\$ 1.75$.

FLORAL TREASURE. Rosefield. 7.5. Very delicate salmon-pink, with green heart; rosy tinge on first opening. Good, upright grower and bloomer. Flower moderately large and full. Foliage light green. A charming flower where delicacy of coloring is desired. $1-2$.

GENERAL BERTRAND. Guerin. 7.1. Deep rose-pink; large guard petals; center well filled with small, salmony pink petals edged with whitish pink. Splendid habit and foliage; nice, elongated bud; in all of which points it resembles Modeste Guerin. It lacks, however, the solid color and firmness of guard petals found in Modeste Guerin. 1-2.

\section{SECTION B}

\section{1 -year, $\$ 1.00 ; 2$-year, $\$ 1.50$}

Each variety can be supplied this year only in years old indicated by figures following description.

ALBERT CROUSSE. Crousse. 8.6. Large, very full, evenly formed bloom; fresh pink, center shaded with clear pink. Petalage small and very dense. A high-class, late Peony of much merit. 1.

ALEXANDRE DUMAS. Guerin. 7.1. A pretty shade of bright pink, with chamois, white, and salmon intermingling; flowers large and very full. A most attractive and showy variety, combining several colors, but in general effect a rich pink. Very good and reliable. 1-2.

ALFRED DE MUSSET. Crousse. 7.5. Large to very Iarge, well-formed, flesh-white flower, shaded pale salmon with rosy center. The general color effect of this variety is exquisitely fresh and pleasing. The habit and flowering qualities are very good. A variety which, in our opinion, should be better known than it evidently is. 1. Also 3-year, $\$ 2.00$.

COURONNE D'OR (Syn., Crown of Gold). Calot. 8.1. Large and full imbricated flower of superb form; white, reflecting yellow, center petals bordered with carmine; golden stamens showing through and lighting up flower. Solidly and perfectly built from edge to center. Fragrant, a good grower and reliable bloomer. Blooms moderately late, preceding Marie Lemoine. 1-2. Also 3-year, $\$ 2.00$.

FELIX CROUSSE. Crousse. 8.4. Large, anemone, ball-shaped bloom. Color brilliant, dazzling red, with ruby-flamed center. Good grower, bloomer and ne of the most popular all-round red varieties. $1-2$. 
JAMES KELWAY. Kelway. 8.7. Large to very large and fuIl white flower; buds flecked with carmine; lower petals delicately tinged with pink, but flower in general is a most attractive pearly cream-white. Occasionally, a few golden stamens will show in center of flower and usually there are enough stamens scattered throughout the flower at base of petals to illuminate it. These are, however, not conspicuous. Fragrance good. Blooms midseason. 1-2. Also 3-year, $\$ 2.00$.

JEANNE D'ARC. Calot. 7.9. Soft pink, sulphur-white, and rose; center spotted carmine. A unique and charming combination of colors. Moderately strong grower; a very free bloomer, flowers invariably coming perfect. The most popular of the tricolored sorts. $1-2$.

MADAME BARILLET DESCHAMPS. Calot. 7.8. Very tender pink, bordered with white and shaded with lively silvery tints; golden stamens reflected throughout flower. A large, full ball of silk and satin, very sweetly perfumed. Good grower, with very distinct broad foliage. 1-2.

MADAME CALOT. Miellez. 8.1. Broad, flesh guard petals; center blush, deepening to delicate crushed strawberry, surrounded with small, strawwhite petals, whole effect flesh-salmon-white fading to white. Flower very large, full, and superbly built; early and fragrant. Growth and stems ideal. Very free bloomer. Not so promising on young plants, but on established ones it is truly superb, and this, together with its sure and abundant blooming qualities, places it, in our estimation, as one of the very foremost low-cost Peonies for general planting. 1-2.

MADAME DE VERNEVILLE. Crousse. 7.9. Exceedingly good, full, anemone-shaped flower. Broad guard petals, sulphur-white; center rosy white, with an occasional edging of carmine; beautifully imbricated. Very sweet, rose-like fragrance. Blooms early and abundantly. 1-2. Also 3-year, $\$ 2.00$.

MARECHAL VAILLANT. Calot. 7.5. Immense, full, purplish red flower, coming on very long stems. The flower is very solid, heavy, and somewhat drooping in habit. One of the last to bloom, but not very prolific as a rule. Always a prize-winner at the late shows. $\mathbf{1}-\mathbf{2}$.

MODELE DE PERFECTION. Crousse. 7.8. Large, full flower, well and evenly formed. Color flesh-pink, marbled with bright rose, deepening in center. Flower opens cup-shaped, then develops to a high-pointed center, which afterwards opens up, making a very high, built-up flower. Good, erect habit; strong stems; a prodigious bloomer. Very distinct and desirable. Blooms late. 1-2.

MONS. DUPONT. Calot. 8.3. Very large, cup-shaped, perfectly built flower. Creamy white, center petals bordered with lively carmine, and lit up with golden stamens at base of petals. Exceedingly rich bloom and deliciously fragrant. Good, tall grower. Blooms rather late, preceding Couronne d'Or. A truly royal flower. 1-2. Also 3-year, $\$ 2.00$.

OCTAVIE DEMAY. Calot. 8.5. Very large and fulI, well-built flower. Rosy blush on first opening, fading to white, with occasional coloring of carmine in center. Color of exceeding freshness. Plant is quite dwarf, but bears regularly and prolifically its very large flowers on stiff, upright stems. Early bloomer. Fragrant. In our opinion this variety is one of the most charming and meritorious of the early Peonies. 1-2. Also 3-year, $\$ 2.00$.

SOLFATARE. Calot. 7.6. Guard petals pure white; center ball-shaped and well filled with narrow, sulphur-yellow petals. The flower is medium large to large, fragrant, and comes on good stems. Exquisitely beautiful. Where a white and yellow Peony is desired we recommend this above all others with the exception of Primevere. Unfortunately, this variety has its off seasons and cannot be classed among the sure, prolific bloomers. 1-2.

UMBELLATA ROSEA. Dessert. 7.4. Broad guard petals, delicate rosepink; center petals short, straw-yellow, with tufts of whitish pink. Habit ideal; flowers borne on stiff, upright stems. Fragrance delicate and agreeable. Blooms young and abundantly. Usually in bloom here by Decoration Day. 1-2. 


\section{SECTION C \\ 1-year, \$1.25; 2-year, \$1.85}

Eacb variety can be supplied this year only in years old indicated by figures following description.

AUGUSTE VILLAUME. Crousse. 7.3. An enormous, deep pink, very fuII flower of splendid form and habit, wonderful substance, but lacking in refinement. Like many, if not most, Iate-blooming Peonies, it will not stand rain but in fair weather opens to a flower which is invariably a prize-winner at the shows because of its unusual size and fullness. Can hardly recommend it to beginners or the owner of a very small collection. 1-2.

EUGENIE VERDIER. Calot. 8.6. Flesh-pink, changing to white in center. An enormous, rather flat flower, coming on exceedingly long stems, gracefully, but not badly, drooping. This is one of the most distinct, impressive and beautiful Peonies in cultivation. $1-2$.

GERMAINE BIGOT. Dessert. 8.5. Large to very Iarge, flesh-pink, fuII flower tinged pale rose. Good upright habit and a good, sure bloomer. Stamens visible throughout the flower. Fragrance good. One of the comparatively few varieties which seemingly never has an off season. 1-2.

LA ROSIERE. Crousse. 8.3. An exceedingly charming, cup-shaped flower. White, with smaII yellow center, suggesting an immense, quite fuII pondIily. Moderately large flower, coming on a bush of moderate height. An appealing Peony of unusual distinctiveness. 1-2.

LOUISE RENAULT. Crousse. Very Iarge and full bloom, petals very broad. Color unique-a solid slatish pink. Fragrance very spicy and the most delightfully refreshing of all Peonies. Good habit and stems. Blooms late. 1-2.

MADAME DE GALHAU. Crousse. 7.5. Enormous, imbricated flower, coming on tall, firm, erect stems. Color soft, glossy flesh-pink, shaded with transparent salmon. A superb, Iate variety of ideal habit, and a good, profuse bloomer. The buds often begin to open one-sided, but they usually develop slowly into prize-winning blooms. 1-2.

MADAME DUCEL. Mechin. 7.9. Large, wonderfully built flower; broad guard petals, center ball-shaped, very fuII and compact. The closely set small petals are beautifully curled, as in a chrysanthemum. Whole flower solid color of silvery Iilac-pink. Foliage very fresh, dark green. Very distinct and floriferous. Blooms early, resembling Mons. Jules Elie. 1-2.

MADAME EMILE GALLE. Crousse. 8.5. Large, cup-shaped, imbricated flower. Soft Iilac-pink; center shaded soft flesh and cream, fading to rosy white. Coloring of great delicacy. Splendid bud. Foliage very distinct, dull green. Late. 1.

MADAME EMILE LEMOINE. Lemoine. 8.9. Large and fulI, globular bloom. General effect rosy, creamy white, a very delicate and fresh coloring. Quite fragrant. Of good habit and a good reliable bloomer. This variety ranks high among the whites. 1-2.

MADAME FOREL. Crousse. 7.7. Flower Iarge to very large and fuII. Color medium shade of silvery pink. Good grower, bloomer, abundant and beautiful foliage. Moderately late. 1-2.

MADAME GEISSLER. Crousse. 7.9. Gigantic, full bloom, rather flat when fully open. Glossy Iilac-rose-pink, shaded to Bengal rose at base of petals. One of the Iargest of aII Peonies. 1.

MIREILLE. Crousse. 7.7. When this variety opens well it is readily classed as a very fine Peony. Like so many other late varieties, however, this desirable condition is not every year reached and we do not recommend it for a small collection. It is of good, strong, upright habit and yields a very Iarge and fuIl milky white flower. $1-2$. 
George H. Peterson, Inc., Fair Lawn, N. J.

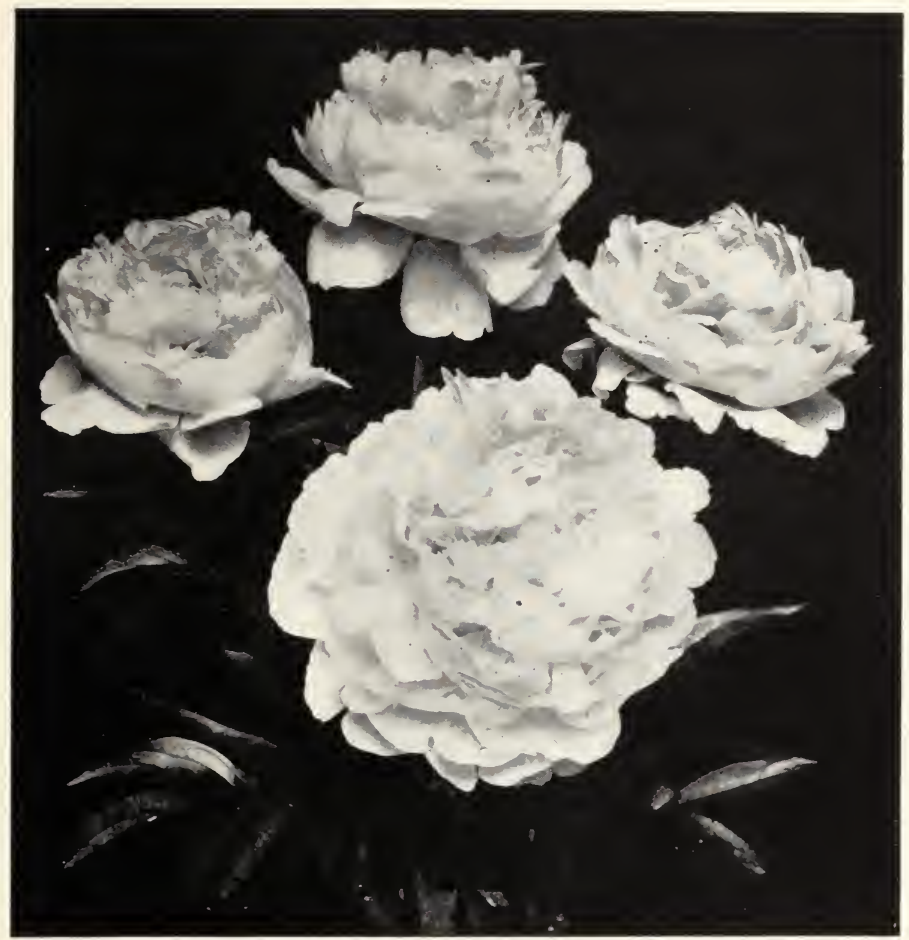

Triomphe de I'Exposition de Lille

MODESTE GUERIN. Guerin. 7.8. Very large, anemone, ball-shaped bloom, perfectly built. Bright carmined pink, solid color. Splendid habit and foliage. Very fine, elongated bud. A choice and distinct very dark pink Peony which can be depended upon to bloom abundantly. 1 .

PHILOMELE. Calot. 7.7. Guard petals soft pink; center a real deep golden yellow with often a center tuft of rose, bordered carmine. Very distinct and sweet syringa-like fragrance. Possesses the deepest yellow to be found in Peonies. Good lasting qualities. One of the most striking varieties. Splendid both as a cut-flower and for garden decoration. 1-2.

SOUV. DE L'EXPOSITION UNIVERSELLE. Calot. 7.6. Very large, full flower. Rich, clear, brilliant pink with silvery reflex. Good, prolific, dependable bloomer. This is, perhaps, the clearest bright pink of all Peonies without a suggestion of purple. 1-2.

TRIOMPHE DE L'EXPOSITION DE LILLE. Calot. 7.8. Large, full and beautifully imbricated flower of perfect form. Soft, fleshy pink, with white reflex; petals exquisitely dotted and marbled with carmine. One of the very best reliable bloomers and almost unequaled in beauty among the light pinks, resembling Reine Hortense. See illustration. 1-2. 


\section{SECTION D}

\section{1-year, \$1.50; 2-year, \$2.25}

Each variety can be supplied this year only in years old indicated by figures following description.

ATROSANGUINEA. Calot. 7.5. Large, fuIl bloom. Color deep scarlet-red, tinged with violet; bright golden yellow stamens showing through flower. Very brilliant and showy. Superb habit. Fragrant. Possibly the most dependable bloomer of all the red varieties. $1-2$.

AUGUSTIN D'HOUR (Syn., Marechal MacMahon). Calot. 7.8. Very large, convex bloom. Broad guard petals; center petals narrow and built up close and high, ball-shaped. Color on opening, deep, rich, vinous red. Strong grower with large, very dark, glossy foliage; stems very stiff. Very good bud. Blooms late midseason. $1-2$.

AVALANCHE. Crousse. 8.7. Very large and fulI, milky white flower of perfect form, reflecting yellow from the base of petals; few center petals often very delicately edged with carmine. Fine, strong, upright grower, good bloomer and delightfully fragrant. Late midseason. Really superb. Despite the large number of white varieties introduced of recent years, many of them high-priced, each season when we come to this variety we feel a desire to place it in the very forefront of white Peonies. 1-2. Also 3-year, $\$ 3.00$.

BARONESS SCHROEDER. Kelway. 9.0. Very large and full creamy white flower of unusual depth and softness. Splendid habit and bloomer. Medium Iate. With the advent of so many other white varieties of recent years, this sort has been somewhat lost sight of in the discussions; it nevertheless possesses a delicacy and charm beloved by thousands of Peony fanciers. 1-2. Also 3-year, $\$ 3.00$.

GISMONDA. Crousse. 8.2. Flower unusually Iarge, full, and perfectly formed. Color light pink, deepening to a distinct circle in center of dark pink or rose. Very late bloomer. A superb Peony when well grown. 1-2.

GLOIRE DE CHARLES GOMBAULT. Gombault. 7.9. Pretty globular extra-fuII flower. Outer petals fleshy pink; center petals narrower and of a clear salmon-flesh color, shaded with apricot, with tuft of pink petals striped with carmine. One of the very best of the many colored sorts. 1-2.

LIVINGSTONE. Crousse. 8.1. Very Iarge, full, evenly formed and shaded bloom. Beautiful soft pink. Good, erect grower and bloomer. Stems tall and stout. Reliable, young bloomer. Season late. Magnificent bud. 1-2.

MADAME LEMONIER. Calot. 8.0. Exceedingly large, full flower, coming on exceptionally taII, erect stems. Color very distinct and attractive-lavender shading to white. This unusually fine Peony is very different from any other in cultivation, and should not be confused with Madame Lemoinier, also a Calot variety. 1-2. Also 3-year, $\$ 3.00$.

MARGUERITE GERARD. Crousse. 8.4. Large, full flower; tall, upright grower. Flesh, changing to soft flesh-white, with creamy white center. A profuse bloomer, opening aII its flowers perfectly. 1-2.

PETITE RENEE. Dessert. Of French origination, this variety, in some stages at least, resembles more or less the Japanese Peonies. As the plant becomes older, however, the center fills and builds up into a very odd and daintily beautiful flower which is so unlike any other Peony as to draw attention at once. We freely recommend it where an odd or different Peony is desired. The general color effect is carmined pink. A profuse, sure bloomer. 1.

RUBRA SUPERBA. Ricbardson. 7.2. Large, full flower; strong grower. Deep, rich, brilliant crimson. Blooms when nearly all other Peonies are gone and possesses great lasting qualities. Fair to good bloomer on old plants, but does not do much the first year or two. 1-2.

SUZANNE DESSERT. Dessert of Mecbin. 7.7. Large and full, broad-petaled flower of a clear china-pink color, with silvery border. Good bloomer, distinct in coloring and very showy, "silky" bloom. 1-2. 


\begin{tabular}{lll}
\hline George H. Peterson, Inc., Fair Lawn, N. J. & I7 \\
\hline
\end{tabular}

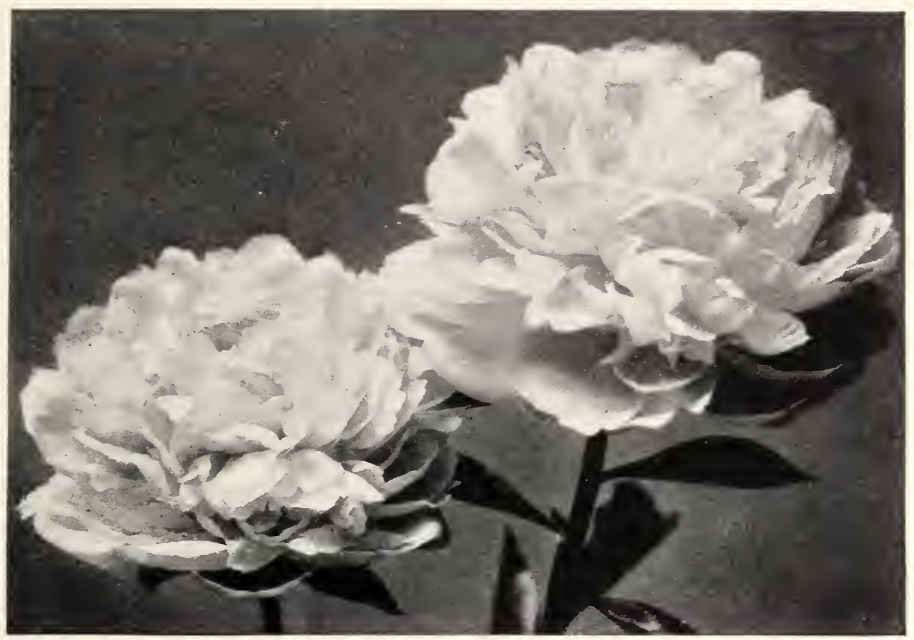

Livingstone. See page 16

\section{SECTION E}

\section{1-year, $\$ 2.00 ; 2$-year, $\$ 3.00$}

Each variety can be supplied this year only in years old indicated by figures following description.

ALSACE-LORRAINE. Lemoine. 8.8. This is a large, late midseason variety. The waxy petals are rounded and cupped at the tips and are symmetrically arranged in a circular form. It is pure white, tinted with cream and buff in the center. The habit of the plant is only moderately vigorous but produces many flowers of fine form and unusual color. 1.

ASA GRAY. Crousse. 8.1. Large, full and perfectly formed bloom. Salmon and fleshy pink; petals beautifully marked and marbled with carmine-lilac. Tall, upright grower, and good bloomer. A dependable high-class distinct variety which must not be passed by. 1-2.

CHARLES McKELLIP. Brand. 7.8. This is a deep, rich red somewhat on the order of Longfellow. The flower is full, quite large, and holds its color remarkably well. Like some of the other reds it does not bloom abundantly each season, but has elicited high praise from some of our customers. 1-2.

CHESTINE GOWDY. Brand. 8.4. This is one of the most distinct of Brand's Peonies. The growth and habit are excellent. The flower, cone-shaped, is exceedingly full to the center, well and evenly rounded, being, in fact, very symmetrically built. It gives us a delightful combination of colors. The outer few rows of petals are delicate lavender-pink. Then comes a rounded section of creamy yellow with the center a similar color to the outer petals, usually quite noticeably marked with purplish red. Blooms moderately Iate. It is too bad that so distinct and attractive a flower was not given a more happy name. $1-2$.

CLAIRE DUBOIS. Crousse. 8.7. Very large, globular flower, extremely full, convex, tufted; petals laciniated and incurved. Color the finest original pink; glossy reflex. Late midseason bloomer. A gem but not any too generous with its blooms. $1-2$. 
EUGENE BIGOT. Dessert. 8.3. Brilliant, velvety crimson-red; flowers fairly large, full, and of splendid form. Rather tall grower, moderately Iate and good bloomer. The best of its color and season. 1-2.

KARL ROSEFIELD. Rosefield. 8.8. Surname changed from "Rosenfield" in 1924 by the introducer. Considering every point which a Peony should possess, this comes nearer to filling all requirements than any red Peony yet produced. In the first place, the plant is of magnificent, strong, erect habit, holding its flowers upright to the end of the season. The bloorn is large to very large, exceedingly full and of a deep, rich crimson-red color which holds well; i. e., does not turn purple in the sun. $1-2$.

LAMARTINE (known also as Gigantea). Calot. 8.2. Large, to immense, very full flower, semi-flat in form and of a most entrancing baby-pink shade with silvery reflex. Blooms quite early. Can be classed among the few very best Peonies in cultivation when well grown, and while it should be in the garden of every connoisseur, it is not what might be called a profuse bloomer and, in consequence, may be omitted where only a very small collection is desired. 1.

LORA DEXHEIMER. Brand. 8.4. Along with Charles McKellip and Longfellow, this variety gives a splendid, full, rich crimson flower, moderately large to large. Like some of our other high-class red varieties, we have found it some years not to be such a dependable bloomer. Nevertheless, since we are so short of good red Peonies in most all classes, we would certainly recommend this variety as being one worth while and one that fills a distinct need amongst our finer red sorts. 1-2.

MARIE CROUSSE. Crousse. 8.9. Very large, full, beautifully formed and rounded rose-type flower of the most distinct and exquisite shade of salmon-pink imaginable, fairly glowing with freshness. In previous years, while we admired this variety greatly, it was then usually of not robust growth and, while there are still other Peonies of much more vigorous habit, our present stock of this variety is of at least good, average growth and splendid blooming qualities. 1-2.

MARIE JACQUIN. Verdier. 8.3. Glossy flesh-white, with rosy tinge to bud. Exquisitely beautiful, moderately full, cupped flower, retaining this form. Flowers on newly set plants and weak growths often come near single. With its wealth of golden stamens in center, this flower suggests our native pond-lily. Fragrance very rich and languorous. Very distinct and fine. Should be in every collection of even moderate size. 1 .

MARIE LEMOINE. Calot. 8.5. There is something about this Peony which never fails to appeal to us even more than most other Peonies do. There is a richness and charm about its yellowish white flowers that only increases with the years. The plant is of quite dwarf growth and one marvels that such a plant can produce so large a bloom and on such a sturdy, erect stem. The bloom is a very full one with petals of great substance, making it a lasting flower when cut. Were this variety among the more recent introductions and were we asked to pay $\$ 10.00$ a root for it we would consider it well worth it. 1.

MONS. JULES ELIE. Crousse. 9.2. Immense, globular, bomb-shaped, very full flower. Glossy, fresh pink, deeper at base of petals; silvery reflex on whole bloom. Glossy, light green foliage. Superlatively fine. When well grown this is the largest and grandest of all pink Peonies; in fact we place this among the ten most desirable sorts in existence. An early bloomer. 1-2.

PASTEUR. Crousse. 8.4. Flower large and full, opening a blush-ivory-white, changing to pure white with creamy center. Tall, upright grower. Of the moderately late to late varieties this is one of the most dependable to both bloom and open well every year. $1-2$. 
PIERRE REIGNOUX. Dessert. 7.4. Very large flowers of a rather unusual shade, termed by the introducer "Tyrian rose"; center slightly flecked with crimson petals bordered with a silver sheen. The flowers come quite early and in great abundance; very fragrant and most distinct. 1.

REINE HORTENSE. Calot. 8.7. If one has the true Calot variety (there is another variety under the same name) he will have an all-round pink Peony of high quality that is difficult to surpass in all-round good points. The flower is large, full, and very evenly formed, moderately light, even pink in shade; buds crimson flecked. Habit very good and always a reliable bloomer, every flower developing perfectly. $1-2$.

VENUS. Kelway. 8.3. Large, full flower coming on tall, erect stems. The color is exquisitely fresh, delicate, seashell-pink. Makes an especially pretty bud and ranks high as a cut-flower, being both a prolific and dependable sort. $\mathbf{1}-\mathbf{2}$.

\section{SECTION F}

\section{1 -year, $\$ 3.00 ; 2$-year, $\$ 4.50$}

Each variety can be supplied this year only in years old indicated by figures ollowing description.

ADOLPHE ROUSSEAU. Dessert. 8.5. This is, perhaps, the largest of all red Peonies. The color is an unusually rich, dark red and holds well. The flowers, borne on stiff, erect stems 4 feet in height, when well grown at three to four years of age, are large to very large and moderately full. When young, this plant will often produce almost single flowers and some of these are likely to appear on the weaker growths of well-established plants. Blooms early. 1-2. Also division, \$2.00.

ELIZABETH BARRETT BROWNING. Brand. 9.2. While this variety has apparently met with considerable favor in the West, with us its behavior for the past seven or eight years would not justify the high rating which the Peony Society has voted it. Our main objection to this variety is that the stems are usually rather crooked and drooping. The flower, while a good white, is only fair in form and quality. The stock we offer, however, is clean and true and came originally from the raiser. 1-2.

FONTENELLE. Rosefield. A desirable "red" variety not yet well known and has not been rated by the Peony Society. Clear, brilliant crimson; semi-rose type. Flowers of medium size coming on long, strong stems. A very early, dependable bloomer, one that we can heartily recommend, especially when good early reds are still scarce. $1-2$.

GRANDIFLORA. Ricbardson. 8.8. Large, full flower, flesh-color, changing to fleshy white; very fragrant. This, a famous Richardson seedling, is one of the very last of all Peonies to bloom. The flower unfolds its delicate beauty slowly and lasts well both on the bush and when cut. Unlike most late Peonies, this variety is almost sure to develop well year after year and, being about the very last Peony we see for the season, it leaves with us an impression of its wonderfully delicate beauty not soon forgotten. 1-2. Also division, $\$ 2.00$.

JUBILEE. Pleas. 8.9. While this is, perhaps, a variety to be omitted by the planter of a small collection, it is one that no Peony connoisseur can afford to do without. There are, admittedly, many white Peonies, but there is no other quite like Jubilee. Enormous in size and very full to the center, it is of distinct, flat form. The color on opening is a creamy ivorywhite which fades to a pure snow-white. The bud is not particularly alluring nor promising, but when the flower is fully expanded on a well-established plant, one has a prize-winning variety. Its chief or only weakness is in its stem, which is of insufficient stoutness to hold up the flower so that one can look it in the face. Perhaps its modesty prompts it to hide this from the casual passer-by. Fragrance fair. 1-2. Also division, \$2.00. 


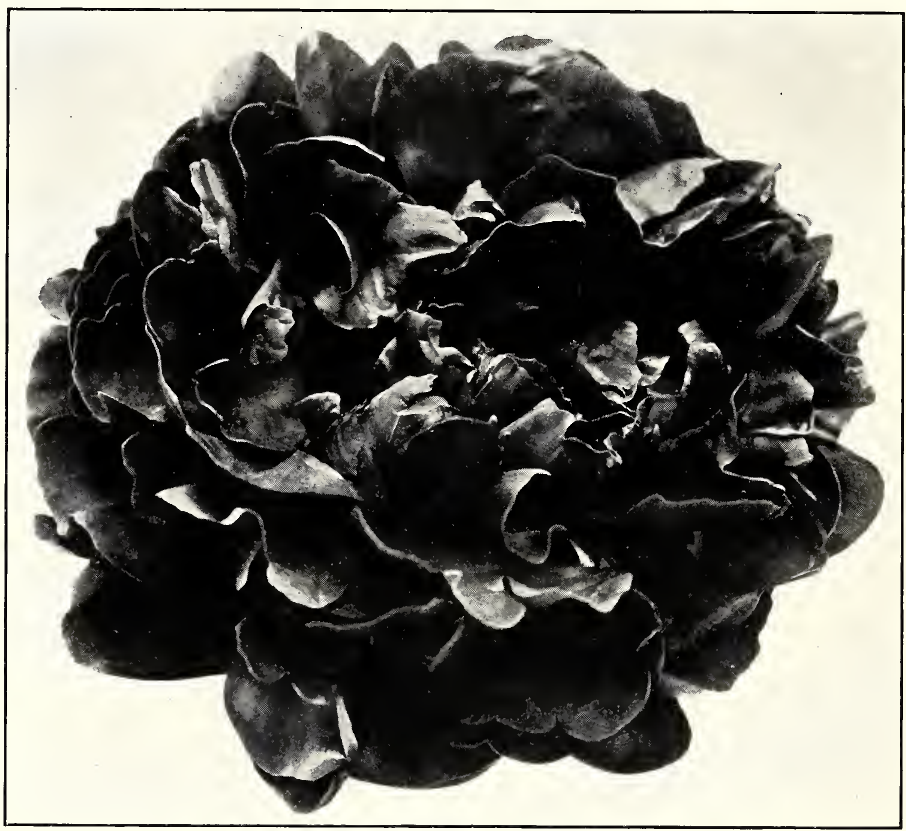

Adolphe Rousseau. See page 19

LADY ALEXANDRA DUFF. Kelway. 9.1. A few years ago this was the most talked-of variety among Peonies. It has often been referred to as the "Long Lost Peony." For a number of years there was a question as to which was the really true variety. This point is now, however, pretty generally settled. The flower is a large to very large one, moderately full and gracefully built, usually showing more or less yellow stamens between the petals which light up the bloom very attractively. The buds are pinkish, very noticeably marked with carmine, and open to a rosy white bloom. The habit is bushy and ideally erect. It produces its blooms lavishly and surely every year and each and every bud develops perfectly. 1-2. Also division, $\$ 2.00$.

PIERRE DUCHARTRE. Crousse. 8.2. Very large, cup-shaped, imbricated bloom, densely crowded with petals. Soft flesh-pink with glossy reflex; silvery border. One of the latest Peonies to bloom, and one of the most perfect and beautiful as well. This variety we have found year after year to be one of the most reliable of the late-blooming Peonies and it is more than worthy of a place in every collection of any size. $1-2$.

SARAH BERNHARDT. Lemoine. 9.0. One of Lemoine's recent gems and should not be confounded with the old Sarah Bernhardt of Dessert, now listed under Umbellata Rosea. This is a really great Peony, soft, even pink in shade, the flower being very large and full, evenly formed, and produced in profusion on a very strong-growing plant. Blooming in what is generally termed late midseason, this is one of the few very fine pink Peonies which can annually be depended upon to bear. prolifically and develop perfectly its wonderful flowers. 1-2. Also division, $\$ 2.00$. 


\section{SECTION G}

\section{Sizes and prices follow each description}

In this section will be found some of the most modern and wonderful Peonies yet produced. Where the price is $\$ 5.00$ or more for a one-year root, we will, if desired, sell a division where so offered, which means a portion of a root as it is divided each faII to set out in the fields and which, a year Iater, becomes a one-year root. Invariably a division is what you will get of these rare varieties when purchasing of other growers, unless the size is specifically stated. And remember, please, you get from us as strong divisions of the rarest sorts as of the more ordinary varieties, i. e., one of 3 to 5 good, strong eyes.

This year, 1931, divisions of the varieties offered in this section will run very heavy because they will be made from a field of fine, heavy, three-year plants which flowered exceptionally weIl.

CHERRY HILL. Tburlow. 8.6. In this we have a new variety of much merit. To begin with, it is one of the earliest of the Chinensis varieties to bloom as it is one of the most prolific and surest bloomers of all the reds. The flower is moderately large, quite fuIl and its deep crimson-red color is similar to that of Adolphe Rousseau. It holds its color and lasts, both on and off the plant, to an unusual degree. The habit is tall and very erect. Meets a real need in the reds. 1-year, $\$ 4.00$; division, $\$ 3.00$.

EDWIN C. SHAW. Tburlow. 9.1. Large to very large, well rounded, cupped, incurved bloom. The color is a most exquisite shade of flesh-pink, deepening noticeably and attractively in center. Ideal, erect habit and profuse, late bloomer. A real gem among the newer Peonies. 1-year, $\$ 16.00$; division, $\$ 12.00$.

ENCHANTERESSE. Lemoine. 8.9. Very Iarge, globular, creamy white flower; buds crimson splashed. Strong, erect grower. Blooms very Iate. It may sometimes be a prize-winning variety, as claimed, but we would hardly recommend it for a small collection. 1-year, $\$ 4.50$; division, $\$ 3.00$.

FRANCES WILLARD. Brand. 9.1. In all-round qualities, it is the best white Peony in existence. The bloom is large, very full, and of splendid, symmetrical form. Like Lady Alexandra Duff, another famous high-class variety, it is of strong, clean growth, good habit, and can be depended upon year after year to bloom well and open perfectly all of its flowers which are exceedingly Iarge in size, fuII, and of wonderful substance. The color is ivorywhite with yellow stamens at the base of the petals which light up the flower most attractively. Occasionally there will be found purplish red markings on the petals with the center ones edged very delicately. Sweet in fragrance and scores close to 100 in every point which a Peony should possess. 1-year, $\$ 5.00$; division, $\$ 3.00$.

JUDGE BERRY. Brand. 8.6. Vey early variety, fragrant, soft pink, resembling somewhat in form and color the well-known Eugenie Verdier. Division, $\$ 4.00$.

KELWAY'S GLORIOUS. Kelway. 9.8. Large to very large, creamy white flower of great delicacy and charm. Very full right to center with very numerous more or less pointed and fringed petals. An occasional flower will show a very delicate purple edging on a few of the petals. Delicate fragrance. Blooms late midseason. This is considered by connoisseurs to be one of the very finest Peonies in existence. $1-y r$., $\$ 12.50$; division, $\$ 8.00$.

LA FRANCE. Lemoine. 9.0. This variety has quite a reputation as a winning exhibition sort. It is a late bloomer, coming on a taII, very erect stem. The flower, which develops slowly, is very large and full, of a light pink shade often referred to as apple-blossom-pink. When fully developed, it is somewhat flat in form. The plant throws up very few growths but every one invariably produces a flower. With us, in common with other very late varieties, it does not always open all of its buds. Division, $\$ 5.00$. 
LAURA DESSERT. Dessert. 8.8. A quite new variety heralded on its introduction as the best so-called yellow Peony yet produced. We rather question if it will surpass or equal Primevere. In the first place, while a reasonably good grower with us, it does not quite equal Primevere in this respect nor does it give us as large a flower. It is, however, a good bloomer. 1 -year, $\$ 5.00$.

LE CYGNE. Lemoine. 9.9. This variety is generally conceded by Peony experts to be the nearest to perfection that a Peony has ever reached. The root sends up comparatively few shoots of moderate height which bear a very full, large flower, densely packed with small petals, of a true, cup-shaped form, i. e., the center is lower than the outer petals and the latter diminish in size as the center is approached. The color at first is milky white, fading to pure white. Fragrance good. From a propagator's standpoint this Queen of all Peonies increases slowly, and as a result of this the price has receded slowly. The possession of this and that of Kelway's Glorious, the oft-recurring dream of Peony-lovers, can now, with more reasonable prices, be more generally attained. 1-year, $\$ 10.00$; division, $\$ 7.50$.

LONGFELLOW. Brand. 9.0. A large, full crimson-red of unusual richness, holding its color remarkably without fading. The plant is of good habit and, while it has proved a good bloomer some years, there are times when it does not produce so well. It is, however, one of the best in this respect of the Brand reds as well as about their best flower in this color. 1 -year, $\$ 4.00$; division, $\$ 2.50$; also 2 -year, $\$ 6.00$.

MADAME GAUDICHAU. Millet. 8.2. Very tall, erect grower, bearing an exceedingly dark blood-crimson-maroon flower, hardly second in this respect to Mons. Martin Cahuzac. Particularly distinct, dark red stems and foliage. The flower is large, moderately full, but inclined to be somewhat irregular in form. Like a number of the other reds, it is inclined at times to be a shy producer. 2-year, $\$ 5.00$; division, $\$ 2.50$.

MADAME JULES DESSERT. Dessert. 9.4. Fairly tall, strong grower and very reliable bloomer, carrying its flowers quite erect. General effect of bloom delicate flesh-pink and straw-white, with deepest tones in center, where more or less blotches of carmine will be found, together with scattering stamens which add to the attractiveness of the bloom. AII flowers invariably open perfectly. Fragrant. Blooms late midseason. Generally placed by connoisseurs in the front row of all fine Peonies and, because of its free and reliable blooming habit, it can well be included in the smallest collection of fine varieties. 1-year, $\$ 4.50$; division, $\$ 3.50$.

MARTHA BULLOCH. Brand. 9.1. This is one of the most distinct, refined, and very finest of all the Brand productions. To begin with, the flower develops into one of the largest of all Peonies. The form is semi-flat, cupshaped, and color a medium pink in center shading to lighter pink as the edge of the flower is approached. It is very full, evenly built, and of a pleasing formation. Foliage light green and rather narrow. Fragrance good. Growth tall and upright. Season medium late. Division, $\$ 7.00$.

MILTON HILL. Ricbardson. 9.0. Like most of Richardson's varieties, this is one of the latest Peonies to bloom, and is considered one of his greatest productions. As the flower opens up in bird-nest form, it is found to be crowded with small, salmon-pink petals of the most exquisite and pure shade, of ten showing distinct, scattered markings of carmine. The general color fades to a blush, creamy white. 1 -year, $\$ 4.50$; division, $\$ 3.00$.

MONS. MARTIN CAHUZAC. Dessert. 8.8. This, the deepest red of all, is often termed "the black Peony." The color is really a deep maroon with blackish lustre. The flower varies in size and fullness, not a few of the blooms, especially on unestablished plants, showing a center of yellow stamens. The plant must be well established to produce typical blooms. Good, erect habit. As this is not a rapid reproducer and the demand for it keeps apace, the price stays about where it was fifteen years ago. 1-year, $\$ 4.50$; division, $\$ 3.00$; also 2 -year, $\$ 6.00$. 


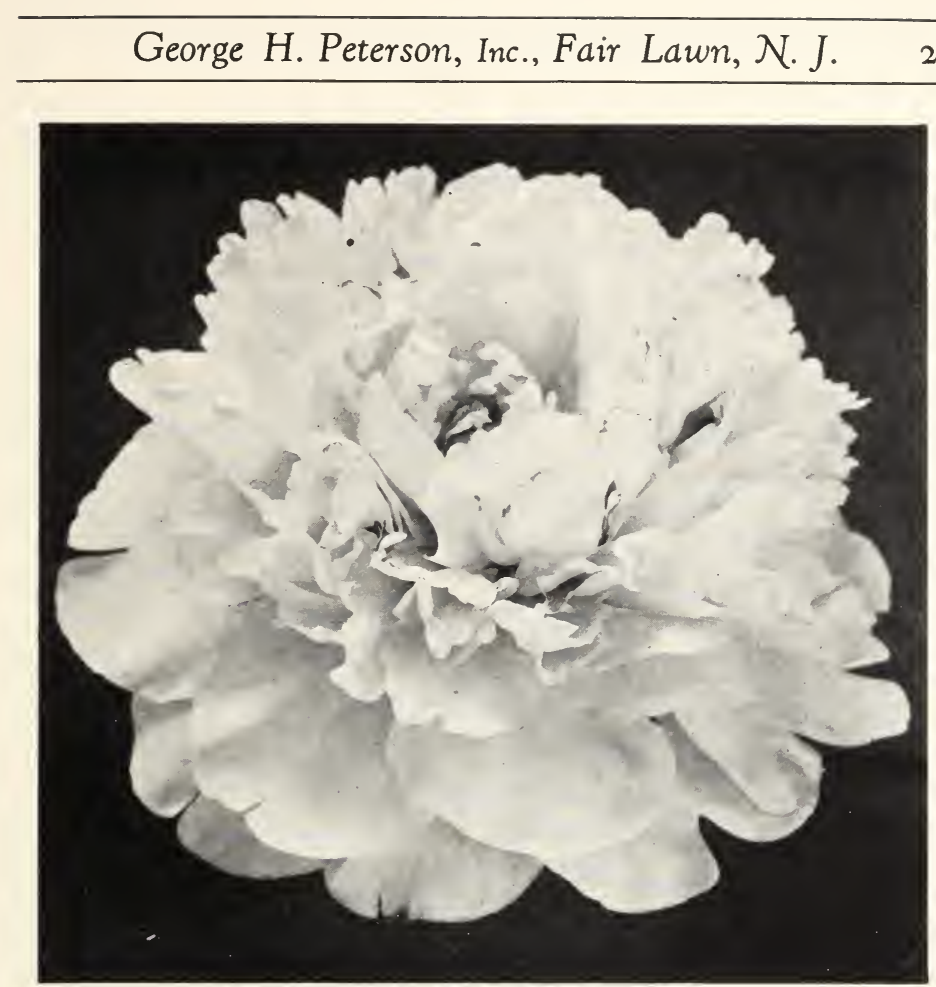

Madame Jules Dessert. See page 22

NYMPHÆA. Thurlow. 8.8. One of the largest and most charming of the golden white flowers which, while full, open up gracefully irregular and somewhat flat. The reflex of intermingled gold upon the white brings a charm which is irresistible. A good, dependable bloomer and distinct addition to the high class whites. 1-year, \$4.50; division, $\$ 3.00$.

PHILIPPE RIVOIRE. Riviere. 9.2. By Peony connoisseurs this is quite often, if not usually, considered to be the best red Peony in existence. From some standpoints this may be true but, for the general planting of the average amateur, we do not fully agree with this opinion. Its price will, of course, debar its wide planting for years to come. From a standpoint of refinement and fragrance, it is in a class by itself. The flower is moderately large, very full, and evenly formed with numerous, moderate-sized petals. The habit is good although not overly strong. The color, a lasting one, while a rich, deep red, is not brilliant but is more soft in tone. Where one can afford the price of this variety, it will be found most distinct and highly desirable. Division, $\$ 12.50$.

PHCEBE CARY. Brand. 8.8. Erect, very tall grower and late bloomer. The flower is very large and full, of good, semi-cupped form. In color it is an exquisitely fresh shade of light lavender-pink, a trifle darker in bud and open bloom than Pierre Duchartre. The open flower somewhat resembles the famous Martha Bulloch by the same raiser but seems to be an improvement on its predecessor in growth and blooming qualities. A regal, stately beauty whose charm and extreme refinement suggest that it should have been named for a princess or duchess. 1-year, $\$ 7.00$; division, $\$ 5.00$. 
PRIMEVERE. Lemoine. 8.6. This was introduced a few years ago as a real yellow Peony. Like the other yellow Peonies, however, it has a single row of large guard petals which a re of a duII white, splashed more or less on the outside with red. The center, of a semi-bomb formation, is a rich sulphuryellow. The plant is a tall, graceful grower and a good bloomer. Fragrance very good. This is generally conceded to be the best of the yellow Peonies so far produced. 1-year, $\$ 4.50$; division, $\$ 3.00$.

RAOUL DESSERT. Dessert. 9.0. Large, full, globular bloom produced freely on a plant of but moderate height. The stems are strong and held erect. The color is described as a mauve-pink shaded with carmine and white, with the pink color deepening most attractively as the center of the flower is reached. Blooms quite late. 1-year, $\$ 8.00$; division, $\$ 5.00$.

RICHARD CARVEL. Brand. 8.8. One of our best large, double, early reds. The color is a clear, bright crimson and unfading, even when open for some time. Excellent for cutting; the stems are tall and strong and the flowers are borne freely. The demand for this variety is increasing and naturally stocks are not any too plentiful. 1-year, $\$ 5.00$; division, $\$ 3.50$.

ROSA BONHEUR. Dessert. 9.0. Plant rather dwarf and bushy, yielding a prize-winning flower large to very large in size, very full, semi-ball shaped, of an even soft pink shade that is most entrancing. Blooms quite late. 1 -year, $\$ 6.00$; division, $\$ 4.00$.

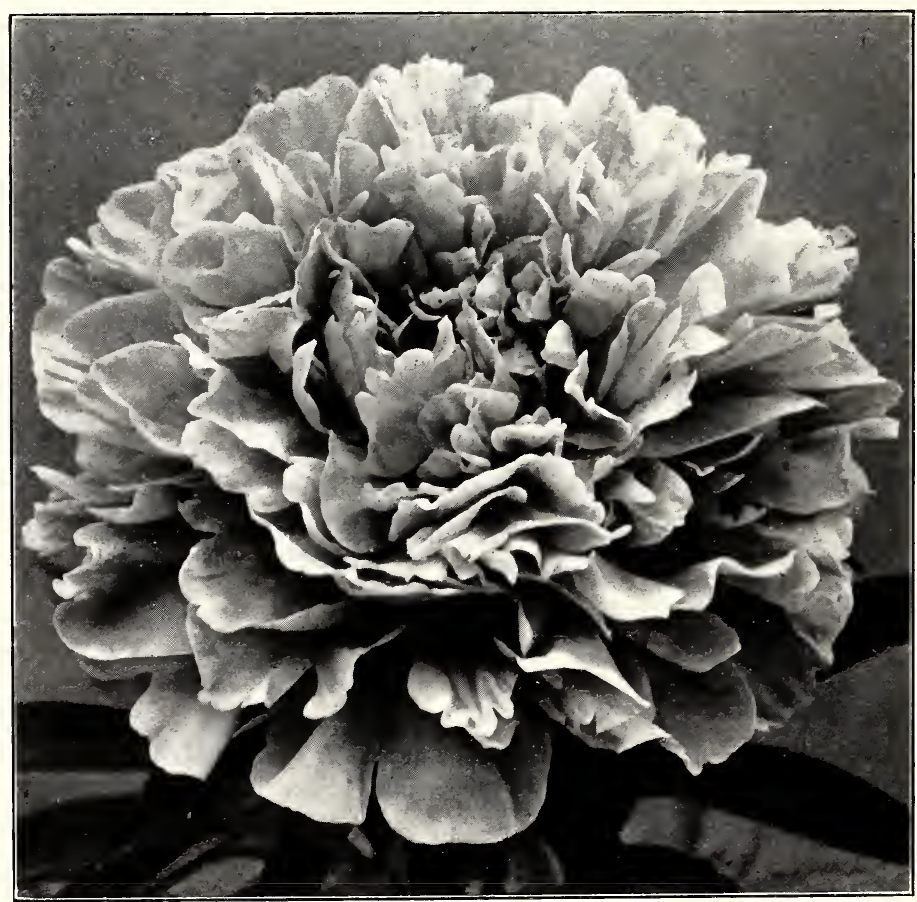

Souv. de l'Exposition Universelle. See page 15

Assistance on selection of varieties cheerfully given 
SOLANGE. Lemoine. 9.7. To say that this is one of the most distinct and remarkable Peonies grown would be to convey but little. The blooms are large to very large and very full, of most unusual substance, and of beautiful, symmetrical, rounded form. The color, however, is its chief attraction and very difficult to popularly describe. Generally speaking, it is a white, but, on first opening, is of a color which were you to take a bowl of cream, add a dash of coffee, and could gather and mix in the rosy glow of a morning sunrise, you would, perhaps, get pretty near to the effect which this flower gives. It is not, however, a prolific bloomer as we can use this term in connection with some varieties, and its one weak point is a stem of insufficient stoutness to hold up in a storm its remarkably solid, heavy bloom which it presents to us late in the season. Mrs. Harding, in her description of Solange in her recently published "Peonies in the Little Garden," says of it: "The color is deep cream, tinged with amber and with a touch of soft salmon-pink blowing from its heart. This rare coloring, in combination with the heavy texture of the petalage, gives the bloom a radiance equaled only by pearls of finest Orient." 1 -year, $\$ 5.00$; division, $\$ 3.00$

SOUV. DE LOUIS BIGOT. Dessert. 9.1. With so many pink Peonies already to choose from, one may, perhaps, wonder how it is possible to produce a new one which will have such compelling qualities as to warrant its introduction. That there is room for a distinct new pink Peony is very evident on beholding for the first time this charming masterpiece of Dessert's. The flower is very large and full, very symmetrically formed, and in color is a very distinct salmon-pink. The growth and flowering qualities are good. Mrs. Edward Harding has the following to say concerning this variety: "Souv. de Louis Bigot is a real treasure. Its effect in the garden is nothing short of gorgeous." 1-year, $\$ 6.00$; division, $\$ 4.00$.

THERESE. Dessert. 9.8. This is one of Dessert's greatest accomplishments, and had he produced but this one Peony, it would have been sufficient to engrave his name on the memory of every Peony-lover for all time. The flower is full to the center, and while immense in size, is one of the most delicately beautiful Peonies in existence. The color is a wonderful blending of delicate pink, Iavender, and white. In addition to its wonderful quality as a flower, it is a profuse and sure bloomer, every flower developing perfectly in every season during the ten or more years we have had it. Even our smallest roots invariably develop flowers the first year. The bush is of splendid, moderately high, symmetrical habit, and distributes its marvelous flowers quite evenly. 1-year, $\$ 5.00$; division, $\$ 3.50$.

TOURANGELLE. Dessert. 9.4. A high-class variety remarkable for its exquisite freshness and beauty, a flower, in fact, of most unusual refinement. The flower is large to very large and very full and comes on long, graceful stems. It is quite densely made up with delicate petals of a pearly white shade, deepening in the center to an exquisite flesh and rose tint. Blooms quite late. 1 -year, $\$ 4.00$; division, $\$ 2.50$; also 2 -year, $\$ 6.00$.

VICTOIRE DE LA MARNE. Dessert. 8.2. This, as its name implies, is a heroic Peony. It is, in fact, one of the most striking and attention-compelling Peonies on our grounds. Large to enormous in size, the flowers are very full and produced very prolifically on a strong-growing bush of splendid habit. The color is described by the introducer as a violescent pink. Some people call it a pink and others a red Peony. While, as stated, the flower is full, it nevertheless shows some yellow stamens intermingled with the petals and occasionally these are quite visible in the center. The flower is fairly fragrant and plant of most vigorous constitution. 1-year, \$5.00; division, $\$ 3.50$.

WALTER FAXON. Ricbardson. 9.3. A flower remarkable chiefly for its very attractive and unusual shade-a coral-salmon-pink. The bloom is full and medium Iarge to Iarge, with petals of a silky texture. While we have many pink Peonies, there is none other of this unusual and striking shade. A warm favorite with Mrs. Harding. We cannot agree with her, however, that it begins to equal Therese in all-round desirability. 1-year, $\$ 5.00$; division, $\$ 3.50$.

Undivided clumps produce many good blooms the first year and thereafter 


\section{Single and Japanese Peonies}

In foliage, habit of growth and bloom, these are similar to the Double Peonies. The Singles bloom very early and freely and can be depended upon to yield good, typical flowers every year regardless of weather conditions. The flowers have but one or at the most two rows of Iarge petals with a wealth of golden, pollen-bearing stamens in center, making a grace$\mathrm{ful}$ and very attractive bloom which is fast becoming the idol of many of our most cultured Peony-Iovers.

The true Japanese varieties likewise have but one or two rows of outer petals, but the stamens, instead of bearing pollen, are developed to form a center cushion or tuft of narrow petals called staminodes. The center is highly colored in striking contrast with the outside petals. Both the Single and Japanese varieties are valuable for accent in garden decoration.

Stocks of these varieties are at present in great demand. They propagate slowly and hence prices are not apt to be lower for quite a few years.

ATTRACTION. Hollis. 8.2. A Iarge, midseason, Japanese type. The flower opens a very vivid red, becoming crimson (described by some as deep Tyrian rose); center of the flower a violet-crimson with edges of staminodes a beautiful golden buff shade. Fragrance pleasing. Division, $\$ 3.00$.

DEFIANCE. Terry. One of the most striking and the most showy of the single Peonies. In color between a pink and a red, a rich cherry. The plant is a very strong grower and enormously productive. The general effect is exceptionally showy. 1-year, $\$ 1.00 ; 2$-year, $\$ 2.00$.

DOROTHY. Kelway. 7.5. A compact-growing, prolific-yielding, pink variety of moderate height, worthy of a wide planting. In color it is somewhat deeper and more even in shade than Princess Mathilde, is more cupped in form, and usually has a full double row of petals. 1-year, $\$ 1.50$.

JAPANESE NO. 3. This is an unusually rich and nonfading, clear, deep crimson; the center is well filled with a wealth of golden staminodes, making the flower exceedingly showy and attractive from quite a distance. Admired in our exhibition gardens by everybody. Very consistent and free bloomer. The Japanese growers of both Peonies and irises frcquently send out stock that does not tally with the descriptions and consequently we designate them by number, giving our own description. This No. 3 variety we selected a few years ago from a very extensive collection of Japanese varieties and we considered it one of the best. 1-year, $\$ 5.00$; division, $\$ 3.50$.

JAPANESE NO. 5. A most attractive bright crimson, lighter in color than our No. 3, and the guard petals of not so heavy substance. Instead of the stamens as in No. 3, they form a tuft of staminodes that are just a bit lighter than the guard petals when first open but soon changing to a violescent crimson. Flower lasts very well. 1-year, $\$ 3.00$; division, $\$ 2.00$.

MIKADO. Japan. 8.6. One of our best and the most popular of the Japanese type. The outer petals are a dark, dull crimson color; the center of the flower is broad and flat, the stamens taking the form of narrow, thick "petals" of a dark rose-red color tipped with a golden buff-yellow. Foliage very good and makes a highly decorative garden variety. 1-year, $\$ 4.50$; division, $\$ 3.00$.

PRINCESS MATHILDE. Dessert. 7.2. A charming French variety, chinapink, splashed and tipped with silvery white. Large flower, good grower and of fine habit. One of the most prolific pink singles. 1-year, $\$ 5.00$; division, $\$ 3.50$.

ROSY DAWN. Barr. 8.5. Blush-white, changing on opening to pure white. Flower very large and one of the very finest of all the single whites. A most prolific, dependable bloomer. 1-year, $\$ 5.00$; division, $\$ 3.50$. 
THE MOOR. Barr. 7.8. Very deep crimson, the darkest red we know of. The flower, of moderate size, is produced freely and possesses unusual lasting qualities. 1-year, $\$ 3.00$; division, $\$ 2.00$.

VICTORIA. A striking red variety of merit. To begin with, the growth is very vigorous and upright, yielding a large, showy, red flower of intermediate shade between the light cherry-red of Defiance and the deep crimson of The Moor. The contrast of this shade of red with its wealth of Japanese-like golden stamens is very marked. 1-year, $\$ 2.00$; 2-year, $\$ 3.00$.

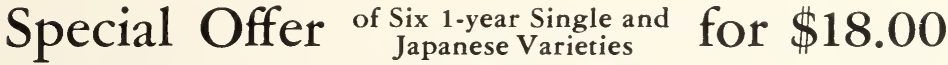

Japanese No. 3.........\$5.00

Japanese No. 5.............. 3.00

Mikado ................ 4.50
Princess Mathilde........\$5.00

Rosy Dawn................ 5.00

Victoria................ 2.00

A division set of the above for $\$ 12.00$

$\$ \overline{24.50}$

\section{"OLD-FASHIONED PEONY"}

OFFICINALIS RUBRA PLENA. This is the old-fashioned red herbaceous Peony of old-time gardens. Its season of bloom is between that of the Tree and Chinese or Albiflora classes, opening freely here in time for Decoration Day. The flower is of moderate size, full and brilliant deep red. 1-year, $\$ 2.00$.

OFFICINALIS ROSEA PLENA. This is the pink variety with the same habit and season of bloom as the old-fashioned red. The flower is a clear carmine-rose of the same size and form as Rubra. 1-year, \$2.00.

\section{Mixed Peonies}

To those who, in the past, have purchased these mixed Peonies of ours, no word as to their quality and desirability is necessary, since these have proved one of the most popular and satisfactory offerings we have ever made, i. e., something which gives most for the money expended. These are sold in strong, two to five-eyed divisions only, such as will, in large measure at least, give some bloom the first season after planting. The roots are made up entirely of named varieties but under no circumstances will they be sold to name or even color.

At the end of a planting season we occasionally have here and there a few varieties left in surplus but not enough to leave out in the field and cultivate same for another season and so, after we have filled our orders and made our own regular planting, we go through the field, dig up the remaining roots, put them all into a truck, divide and plant out and in two years they are ready to redivide and offer.

One who is familiar with Peonies will be able, when blooming time comes, to name many if not most of these and will find among them some high-class varieties although not, of course, those of the rarest and highest priced kinds.

Where one desires a mixed, massed, border effect or plenty of flowers for cutting, regardless of name, these mixed divisions of ours offer a rare opportunity.

25 roots for $\$ 10.00 ; 50$ roots for $\$ 17.50 ; 100$ roots for $\$ 30.00$ SOLD IN ABOVE QUANTITIES ONLY 


\section{Peony Collections}

These are made up from our best stock of the current year and are especially recommended to anyone desiring a small collection but who is unacquainted with the merits of the different varieties. It is an excellent way to get a start in choosing one's favorites which may Iater be ordered in separate varieties. By referring to the descriptions on the foregoing pages, you will note that our selections are made to include a wide range of color-whites, pinks, and redswhose flowering season should extend well over the whole month of June.

A special price is made where the unbroken set is taken; these special prices are net and discounts offered on page 9 will not apply here.

\section{STANDARD COLLECTION}

\begin{tabular}{|c|c|c|}
\hline 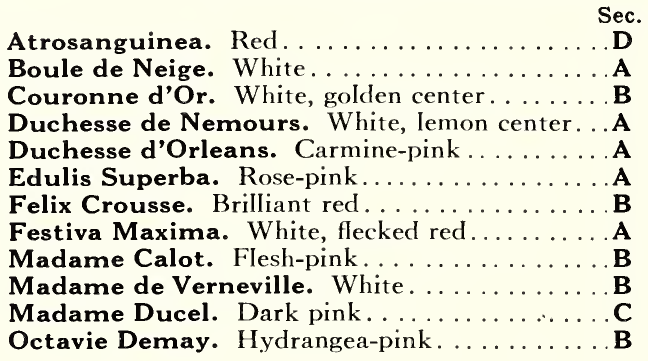 & $\begin{array}{r}1-\text { year } \\
\$ 1.50 \\
.75 \\
1.00 \\
.75 \\
.75 \\
.75 \\
1.00 \\
.75 \\
1.00 \\
1.00 \\
1.25 \\
1.00\end{array}$ & $\begin{array}{r}2-\text { year } \\
\$ 2.25 \\
1.25 \\
1.50 \\
1.25 \\
1.25 \\
1.25 \\
1.50 \\
1.25 \\
1.50 \\
1.50 \\
1.85 \\
1.50\end{array}$ \\
\hline & & \\
\hline
\end{tabular}

\section{ROYAL COLLECTION}

\begin{tabular}{|c|c|c|}
\hline 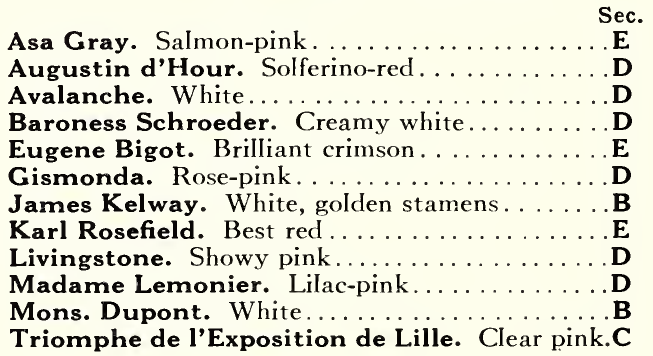 & $\begin{array}{r}1-\text { year } \\
\$ 2.00 \\
1.50 \\
1.50 \\
1.50 \\
2.00 \\
1.50 \\
1.00 \\
2.00 \\
1.50 \\
1.50 \\
1.00 \\
1.25\end{array}$ & $\begin{array}{r}2 \text {-year } \\
\$ 3.00 \\
2.25 \\
2.25 \\
2.25 \\
3.00 \\
2.25 \\
1.50 \\
3.00 \\
2.25 \\
2.25 \\
1.50 \\
1.85\end{array}$ \\
\hline & & \\
\hline
\end{tabular}




\section{DIAMOND COLLECTION}

\begin{tabular}{|c|c|c|}
\hline Adolphe Rousseau. Rich dark red... & $\begin{array}{c}\text { 1-year } \\
\$ 3.00\end{array}$ & $\begin{array}{r}\text { 2-year } \\
\$ 4.50\end{array}$ \\
\hline $\begin{array}{l}\text { Adolphe Rousseau. Bich dark red... } \\
\text { Charles McKellip. Bright crimson. }\end{array}$ & $\begin{array}{r}\$ 3.00 \\
2.00\end{array}$ & $\begin{array}{r}\$ 4.00 \\
3.00\end{array}$ \\
\hline Duchesse de Nemours. White, lemon center. & .75 & 1.25 \\
\hline estiva Maxima. White, flecked crimson.... & .75 & 1.25 \\
\hline ontenelle. Pure crimson. ............. & 3.00 & 4.50 \\
\hline iflora. Bright rose-pink . . . . . . . . & 3.00 & 4.50 \\
\hline Alexandra Duff. Very distinct pink. & 3.00 & 4.50 \\
\hline Gerard. Hydrangea-pink.... & 1.50 & 2.25 \\
\hline tin Cahuzac. Darkest red...... & 4.50 & 6.00 \\
\hline ense. Brilliant pink, silvery tips. & 2.00 & 3.00 \\
\hline arah Bernhardt. Soft pink, golden center. & 3.00 & 4.50 \\
\hline ourangelle. Pearly white to rose......... & 4.00 & 6.00 \\
\hline & $\$ 30.50$ & \\
\hline & $\$ 23.00$ & $\$ 34.0$ \\
\hline
\end{tabular}

\section{THE DE LUXE COLLECTION}

Occasionally we have an inquiry for a collection of the choicest and rarest Peonies in existence, and this set, also at a special net price, is made up to meet this demand. We congratulate anyone who has the means to possess and the faculty to appreciate and enjoy such gems as these.

Sec. 1-year

Cherry Hill. Rich dark crimson ................ G $\$ \mathbf{\$ 4 . 0 0}$

Kelway's Glorious. White, very fragrant.......... G $\quad \mathbf{1 2 . 5 0}$

Le Cygne. Perfect white, tinged ivory . . . . . . . . . G $\quad 10.00$

Mons. Martin Cahuzac. Darkest red ............. G 4.50

Nymphæa. Pale rosy white, golden center........... G $\quad \mathbf{4 . 5 0}$

Primevere. Nearest approach to a yellow Peony .......G G $\quad 4.50$

Richard Carvel. Brilliant crimson, unfading .......... G $\quad \mathbf{5 . 0 0}$

Solange. Creamy white to buff to pale pink.......... G $\mathbf{5 . 0 0}$

Souv. de Louis Bigot. Bright rose-pink. . . . . . . . . . G $\quad \mathbf{6 . 0 0}$

Therese. Delicate pink to lavender.............. G $\quad \mathbf{5 . 0 0}$

Victoire de la Marne. Violescent-pink........... G $\quad \mathbf{5 . 0 0}$

Walter Faxon. Coral-salmon-pink ................ G $\quad \mathbf{5 . 0 0}$

$\$ 71.00$

The set for $\ldots \ldots \ldots \ldots \ldots \ldots \ldots \ldots \ldots \ldots \ldots \ldots . \ldots \ldots$

The prices for collections include delivery charges prepaid

Note.-These collections are especially made up to include only those highly rated varieties that are noted for their dependable year-in and year-out blooming qualities over the widest range of climatic conditions. Both one- and two-year old roots will bloom the first year when planted according to directions; the older and larger roots will naturally give a greater immediate effect. In either size, the roots are sent to you as undivided, mature clumps with at least five to ten well-developed "eyes." 


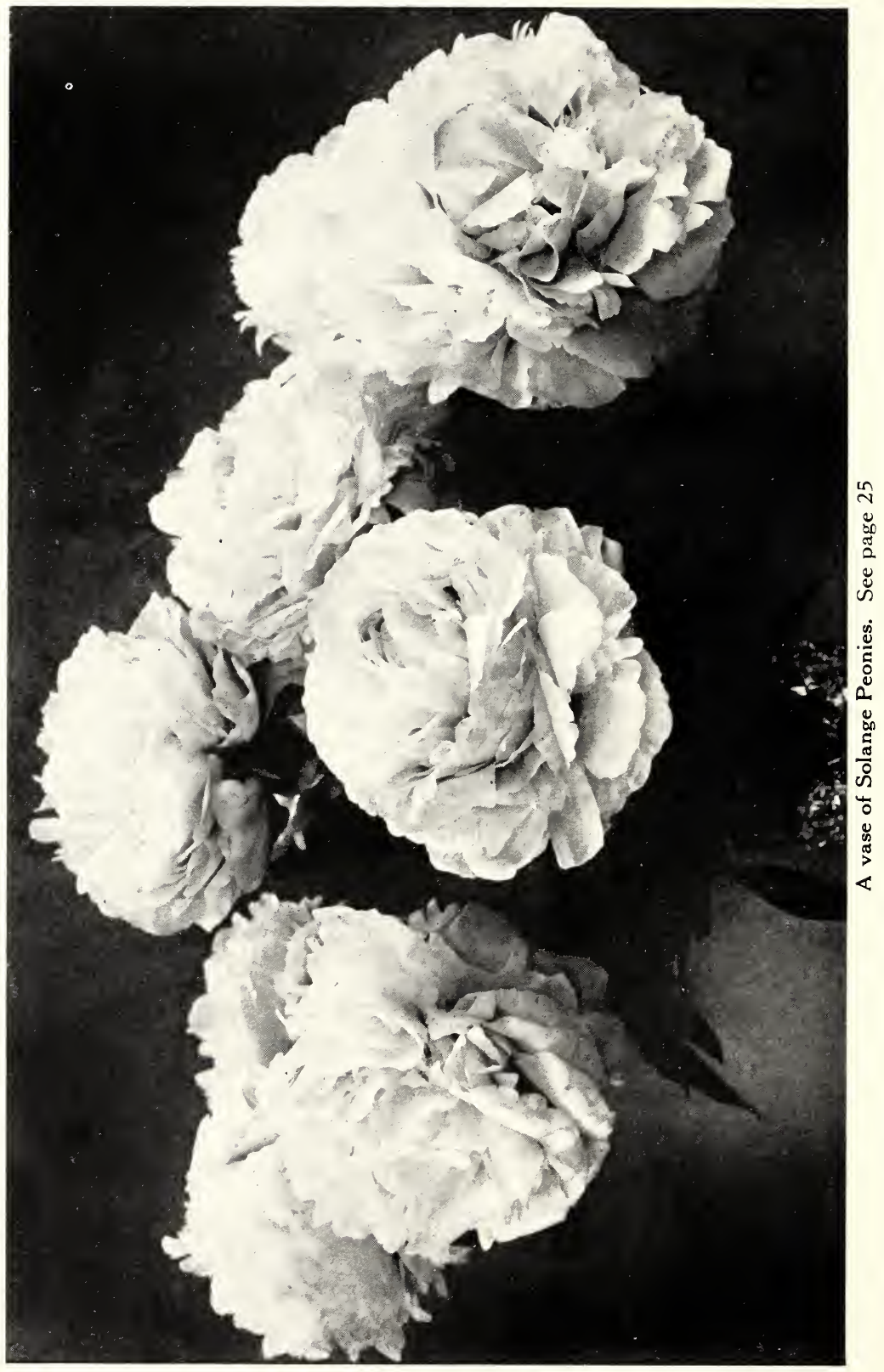




\section{Planting and Cultivation}

The Herbaceous Peony is of such simple culture, and so easy to grow, that but little instruction will be necessary in order that the beginner may produce the finest blooms. While it will grow and bloom under conditions in which most plants would perish, it will well repay, in Iargely increased size and beauty of bloom, a thorough preparation of soil.

\section{Preparing the Ground}

Let us suppose you already have a garden soil where you have successfully grown other garden flowers or good crops of vegetables. So Iong as there have never before been Peonies planted in such a soil, perhaps little further preparation at time of planting will be necessary. Subsequent feeding and fertilizing (see "Later Fertilizing") will be sufficient but important in such cases.

Where quite a large planting of Peonies is to be made and there is no loamy garden soil available, then it will repay you to prepare a special bed. Dig out about 12 to 18 inches of the inferior soil and bring in better soil in which rotted manure may be thoroughly incorporated with a fork as long before planting time as possible. If fresh manure must be used, it should be reforked in and through the soil several times during the summer before planting time. Only a reasonable amount of manure should be used because there is a danger of it causing root rot where it is not thoroughly incorporated in the soil.

Ground bone or bone meal, coarse as possible, may, to advantage, also be mixed through the soil before planting, using about a pint to a plant.

\section{Character of Soil}

Peonies will grow and bloom in both clay and sandy soils. The latter, if not too sandy, will yield more growths and blooms, but a clay soil, while giving fewer growths and flowers, will produce stronger and larger ones.

Probably the very best soil for the Peony is one which is neither too heavy with clay nor too light with sand, one which might be termed a heavy loam, and such as would make a good vegetable garden. Such a soil should be fairly retentive of moisture, and the Peony, being a strong quick grower, can absorb much water.

Never plant the Peony in soil in which Peonies have grown before, or until at least six or more years have elapsed. Disregard of this will result in comparative or even complete failure.

\section{When to Plant}

Peony roots may be planted with absolute safety from early September until just before the ground freezes up for the winter. A September or early October planting will, however, show better results the first summer than a planting made later in the fall. New rootlets develop in the fall, if roots are in the ground in time, and these contribute noticeably to the top growth next season.

In southern latitudes, where prolonged spells of warm weather are likely to be experienced in Iate faII, and which would have a tendency to prematurely start the dormant eyes or buds, mid-October may be quite early enough to plant. 


\section{Depth and Distance to Plant}

It is most important that the root be set in the ground so that the main or larger eyes at the top of the root are about 2 inches beneath the surface of the ground in heavy soil or 3 inches in light soil after the same is leveled off. If planted too deep, say more than 3 inches at most, the spring growths will be slow in appearing, they will not be so strong and will of ten come blind, i. e., produce no flowers.

Set the roots $2 \frac{1}{2}$ to $3 \frac{1}{2}$ feet apart according to room at one's disposal. When planted in field for cut-flower purposes, the plants should be set $31 / 2$ feet apart in row, and rows from 4 to 5 feet apart, or plant $4 \times 4$ to permit cross cultivation.

\section{Watering}

Unless the ground is dry no water need be applied when planting is done in the fall. In the spring, after growths appear above ground and rains prove infrequent, copious waterings will be very helpful in promoting strong growth and producing Iarge blooms. From the time buds begin to show color, care should be exercised to keep them and the open flowers as dry as possible, confining the water, as much as possible, to the ground.

If the soil is fertile, plain water will be best to use, and if necessary to use manure-water, apply in weak solution.

\section{Later Fertilizing}

In the early spring, following the planting, an application of a good prepared commercial fertilizer (the average vegetable brand will do) may be given. As soon as the tops begin to appear above ground, scatter two handfuls around each plant and work it lightly into the soil. Some three weeks or so Iater another similar application may be given or in place of either one of these a finely ground grade of bone meal may be used. Shortly after the flowering season is past, about a pint of bone meal and wood ashes, half and half, may be applied.

\section{Wintering}

So far as protection from cold is concerned, the Peony does not ask it in even the most severe climate. The first winter, the roots, being loose in the ground, will require a light protection (an inch or so) of strawy manure or other porous material. After this, if the ground has been made deep and fertile, as directed, we would advise withholding all manure and protection for several years, and, when it does again become necessary to fertilize, the manure should be broadcast or placed between the plants rather than placed directly over the crown of the plant, which latter, study and observation have shown us, of ten induces decay to set in.

Where old manure has not been obtainable to mix with the under strata of soil at the time of preparing bed, new manure may be applied in November as a mulch between the plants.

A heavy mulching, having to some extent the same effect as a deep planting, will often be followed by blind growths or buds which fail to develop. (See "Why Some Peonies Do Not Bloom.") 


\section{When the Growths Become Too Dense}

From the fifth or sixth year onward after planting, some varieties (according to habit) will begin to throw up too many growths, with the result that the stems will not be so stout nor so tall and the flowers will be smaller than before.

To overcome this, take a pair of sharp-pointed shears when the growths are 8 to 12 inches high and cut off close to the ground a number of them here and there so that those remaining are about evenly spaced. A marked improvement will at once be observed and in a degree depending upon how few growths are left.

\section{After the Blooming Season}

The plants will make no further top growth after the blooming season is over. Keep the ground about them stirred and free from weeds, and water need be applied only when ground is quite dry.

Seed-pods and remains of flowers may be cut off, but do not under any circumstances remove foliage until late October. We repeat this since we have known people to cut off all foliage to the ground soon after the blooming season was over, and then next season wonder why they have little or no bloom.

\section{Why Some Peonies Do Not Bloom}

As this is a question sometimes asked, we will here answer it for the benefit of all interested.

In the first place, a Peony root, whether large or small, recently transplanted, will usually throw up more or less blind shoots, or with small buds which fail to develop. This effect will also of ten be produced by too deep a planting or too heavy a mulching over winter. (See "Wintering.")

Occasionally very severe late frosts, after the plants are above ground, will destroy some of the coming blooms. This rarely happens, however, and never are the plants themselves harmed by such late freezes.

Lack of moisture or fertility will also affect the blooming qualities of a plant. The Peony requires much moisture during the few weeks preceding its blooming time-afterward, having by June made its entire growth above ground for the season, moderate moisture will do.

The ground should not, however, at any time be permitted to get so dry that the plant will wilt, otherwise the eyes forming below the ground will suffer.

Then again, there are many thousands of Peony plants all over the country which should never have found a place in the private garden. A grower raises seedling Peonies by the acre. He must cultivate them several years before they bloom, and when they do bloom he finds a few or none that are as good as varieties already in existence, but lacking the courage to dig them up and throw them away, he sells them to the average nurseryman, to whom all roots look alike, and thus they find their way into the planter's hands. Very probably many of these seedlings have never bloomed and some of them probably never will.

In our own tests of varieties, one that does not begin to bloom within two or three years from planting is discarded, and it must be a very distinct and unusually good variety to be retained and offered here if it does not bloom well and regularly every season after having become established. It is true that there are some varieties which are tardy in beginning to bloom. Take, for instance, Richardson's Rubra Superba, a variety we scarcely ever get flowers from the frrst two seasons after planting, but it is such an 
unusually fine Peony, and blooming when practically all other Peonies are gone, it must be retained.

Of course, there will always be some blind growths, even on wellestablished plants. A fruit tree does not mature all its blossoms, and some years a potato plant yields three times as much as in another season. But, taking it all in all, the Peony is a plant of easy culture, and year in and year out will, with ordinary care, give a good account of itself.

\section{Diseases and Insects}

The Peony is practically immune from general diseases. See to it that you get healthy plants to begin with, and then you will have little to fear.

If you obtain sickly looking roots it is usually due to the grower having raised them on land where Peonies had been growing before. Some growers, after digging and selling certain varieties, will propagate and replant each year the same varieties in the places where roots of the same kind had earlier in the season been dug. In this way they may have one, two and threeyear-old roots in the same row and save much ground space, but it is a most pernicious practice. From the beginning we have never resorted to this, but each year our plantings have been made in soil new to the Peony. As a result our roots are of most unusual vigor and bloom-producing qualities.

During a very wet spring season some foliage, buds, and even stems will rot, but unless the whole plant is affected (and this has practically never happened here among the many thousands of plants we grow yearly), one need not be unduly alarmed. Growths so affected should at once be closely removed and destroyed.

The only insect which ever, even slightly, injures the Peony is the rose chafer, which will sometimes be found eating the petals of the flower. With the exception of the later varieties, the Peony is usually done blooming ere this pest appears, and so it would perhaps be wise, where the chafer is annually very troublesome and one has no inclination to combat it, to omit the later sorts. The Peony is, however, so very large, with dense petalage, that this bug, when it does attack a flower, usually buries itself in the petals, and does not disfigure it as it does a rose or other flower.

Ants, which are often seen on the buds as they are developing, are there to gather a sweet, gum-like substance which the bud exudes. They do no harm to the coming flower nor to the plant, and will disappear on opening of flowers.

\section{American Peony Society Ratings}

The figures in back of the introducer's name of each variety represent the ratings placed upon the different varieties by a vote of the members of the American Peony Society. For instance, the figures 8.9 following Madame Emile Lemoine show its comparative standing in a vote where 10 represents perfection. These ratings are a fair measure of the merit and desirability of certain varieties so $f a r$ as the individual flower is concerned. The freedom with which varieties bloom must also be considered. For general garden purposes, a variety that has a rating of say 7 to 7.5 may be more valuable than one rating 8 or better because the former may produce its flowers more perfectly and consistently every year and under varying weather conditions. 


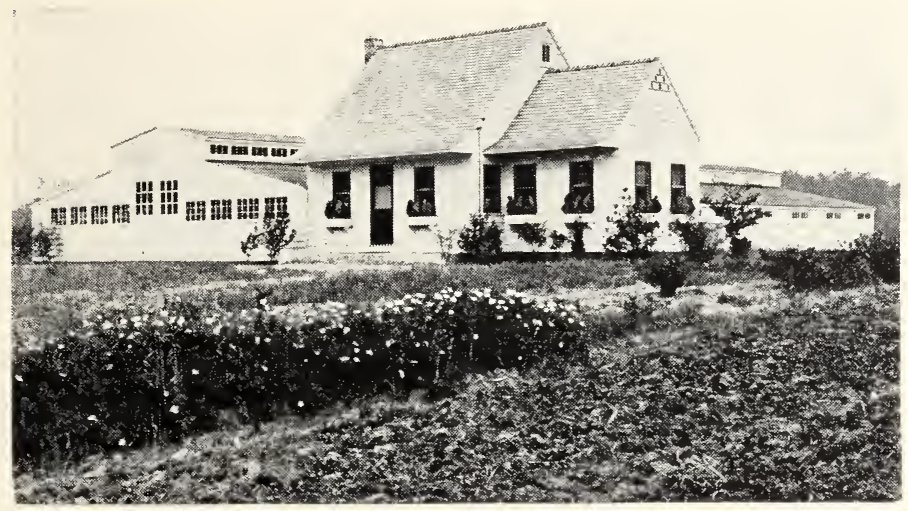

Combined unit of office and storage buildings

\section{How to Reach Our Nursery} office.

By Train: Erie Railroad to Fair Lawn or Ridgewood. Telephone

By Bus: Forty-first Street and Seventh Avenue Bus Terminal, New York City. Take Ridgewood, N. J., bus and get off right at the Nursery, one mile north of Arcola Bridge.

By Motor: From New York, main road from New York to Tuxedo, half-way between Hackensack and Ridgewood on the Paramus Road. If coming directly to Fair Lawn, drive three miles east on Fair Lawn Avenue to Paramus Road.

Location: On the Paramus Road (Franklin Turnpike) in Paramus Borough, one mile north of the New Route 4 State Highway Bridge crossing the Saddle River in Arcola. The Paramus Road is at present designated as N. J. Route 2, main road from Hackensack to Tuxedo, N. Y. In anticipation of traffic from the new bridge over the Hudson at 175th St., New York City, Route 2 will be changed in another year. We are in the center of five-mile distances from Paterson, Ridgewood, Hackensack, and Oradell; two and one-half miles east of the Fair Lawn station and the new city called Radburn.

Do not look for us directly in Fair Lawn. The old Peterson farm has been sold and hundreds of new homes are now built on the acreage where Roses and Peonies were growing a few years ago.

Visitors Are Always Welcome. Peonies are usually at their height June 5-10. Roses in the field are best from Iate June on through October. Write for more definite information. 


\section{Do We Make Good?}

The following extracts are from letters received since our last year's Peony Catalog went to press. They are but a very few of many like letters which have been received during the year. We think they will, however, be sufficient to convince a prospective purchaser to whom we are unknown that our roots are the best that skilled and loving effort can produce and that money can buy.

These letters have all come to us entirely unsolicited, permission to print them having afterward been asked and obtained. The recent replies to our letters asking this permission, and printed here in italics, are even more interesting than the originals. Everyone was willing and pleased to tell us how well many of their Peonies flowered this first spring after planting.

Nelliston, N. Y., October 24, 1930.

The roots are what you said they would be. The service cannot be beaten. I have set out several hundred Peonies and can say that never have I had better service. LATER, under date June 13, 1931: Yes, the Peonies are now in bloom and are very satisfactory.- N. Berton Alter.

201 Bank Ave., Riverton, N. J., October 1, 1930.

Thank you so much for your prompt attention to my order and the beautiful roots you sent me. They arrived in fine condition. LATER, under date June 15, 1931: Yes, I was delighted with the way the Peonies bloomed. Therese was gorgeous!-Mrs. H. McIlvain Biddee.

40 Lincoln St., New Haven, Conn., November 24, 1930.

I wish you could see your Peonies here. They have been a joy ever since I put them in - two with from 40 to 50 blooms on each plant. They are a wonderful sight each June. LATER, under date June 13,1931: Yes, the Peonies were lovelier than ever this year.-Miss K. W. Carmalt.

109 Bosley Ave., Suffolk, Va., October 15, 1930.

I could not have picked more beautiful roots had I entire choice in the matter. LATER, under date June 16, 1931: Certainly you may use anytbing I sav about your plants, botb Peonies and roses. Every Peony bloomed well. My roses (all of wbich are Peterson roses) bave been the wonder and joy of the neigbborbood.-MRS. A. S. ELEY.

281 EIm Ave., Teaneck, N. J., October 27, 1930.

The roots came through very promptly and are entirely satisfactory. LATER, under date June 14, 1931: The Peonies were most satisfactory - all bave bloomed.-M. HENRIKSEN.

63 Larchwood Drive, Cambridge, Mass., October 27, 1930.

Such fine, sound stock! You weren't under the least obligation to replace, yet you sent as fine roots as if this were a fresh order, and again, perfectly packed. I shall take great pleasure in recommending you to all who need Peonies.-A. H. Herrick.

1071 Iranistan Ave., Bridgeport, Conn., November 1, 1930.

My Single Peonies were perfectly splendid plants, so strong and healthy looking. I can hardly wait for spring to come and the Peonies to bloom so that I may enjoy the change from my non-blooming kinds to the new varieties.-Mrs. Philip L. Holzer.

Ship St., Hingham, Mass., September 30, 1930.

I wish to acknowledge the Peony roots which came last week. The man who planted them said what fine roots they were and in what fine condition they were sent. I knew all that before-Elot HubBard. 
North Girard, Pa., September 17, 1930.

Enclosed is an order for Peonies. Three years ago I sent you an order for one of your collections; they all blossomed that year. This y ear they were gorgeous. My friends could not say enough about them.Adelaide Kelley.

346 Adams Ave., Scranton, Pa., May 8, 1931.

I purchased some Peony roots from you last fall, which pleased me in every respect. I also purchased Peony roots from other sources, but I must admit that the type of roots you sold are 100 per cent superior to the others I purchased. LATER, under date June 15, 1931: My neigbbors do not believe that I planted my Peonies only last October, 1930.-A. L. LEDERER.

Ridgewood Terrace, Chappaqua, N. Y., September 19, 1930.

Peonies received. They are splendid roots and will surely bloom next summer. LATER, under date June 14, 1931: I bave been well pleased indeed with your roots and am looking forward with pleasure to your 1931 catalog. I always enjoy them.-Mrs. WM. L. McLaughlin.

Mt. Pulaski, III., September 8, 1930.

I bought 22 Peonies of you fifteen years ago. AII are still blooming beautifully.-Mrs. Emily Maurie.

Whitewater, Wis., October 9, 1930.

I received the Peony roots that I ordered from you Monday morning, just five days after mailing my order, which I would call about 100 per cent in efficiency in filling the order. The roots were fine, well packed, and arrived in good condition. LATER, under date June 17, 1931: Yes, certainly! The Peonies bave all come up to make nice large strong plants and are blooming now. That's giving a good account of themselves the first season.- - OTto A. Reichel.

13943231 st St., Rosedale, N. Y., September 18, 1930.

The roots appeared none the worse for the delay in opening the package, which is a tribute to the careful work of your packing department. In fact, the roots were so plump and firm they looked as though they had just been dug. I shall be glad to recommend your firm to anyone interested in Peonies. LATER, under date June 15, 1931: You may quote any or all of my letter. I cannot recommend your firm too bigbly.-HARRY T. THORNE.

112 Bay Driveway, Manhasset, N. Y., September 19, 1930.

I write to thank you for the splendid Peony roots which I received from you. They are being most carefully planted, in accordance with the directions in your booklet. LATER, under date June 16, 1931: Yes! They bave all flowered and I am delighted with them. I only wish $I$ bad room for more.-MRs. L. WICKENDEN.

869 EIlair Place, Grosse Pointe, Mich., October 12, 1930.

The Peony roots I ordered from you arrived in excellent condition, and I am more than pleased with them. They are by far the finest roots I have ever had from anyone.-Mrs. L. B. Young.

680 W. Ferry St., Buffalo, N. Y., October 30, 1930.

We put in your Peonies several years ago and are now reaping the glorious results. This year was really their first fully grown season and they were lovely.-Mrs. DeWitt H. Sherman.

1829 Burnette Ave., Cleveland, Ohio, September 4, 1930.

Your plants last year were most satisfactory and you might be interested to know that every one bloomed the first year, and that not one of the roots I bought elsewhere bloomed. That might indeed be called "proof of the pudding" as to paying a little more and saving a year's time; and at that I do not yet know whether the other roots will bloom next spring.-A. R. WILLARD. 


\section{Index of Varieties}

Page

Adolphe Rousseau. . 19

Albert Crousse. . . . . 12

Alexandre Dumas. . 12

Alfred de Musset. . . 12

Alsace-Lorraine . . . . 17

Asa Gray..... . . . . 17

Atrosanguinea . . . . 16

Attraction........26

Auguste Villaume. . 14

Augustin d'Hour . . 16

Avalanche........16

Baroness Schroeder. 16

Boule de Neige..... 11

Canari..........11

Charles McKellip. . 17

Cherry Hill. . . . . . . 21

Chestine Gowdy... . 17

Claire Dubois. . . . . 17

Couronne d'Or. . . . . 12

Defiance........26

Dorothy .........26

Duchesse d'Orleans. 12

Duchesse de $\mathrm{Ne}$ mours......... 12

Edulis Superba . . . . . 12

Edwin C. Shaw..... 21

Elizabeth B a r r t t

Browning.......19

Enchanteresse.....21

Eugene Bigot. . . . . 18

Eugenie Verdier... . 14

Felix Crousse..... . 12

Festiva Maxima....12

Floral Treasure. . . . 12

Fontenelle........19

Frances Willard....21

General Bertrand... 12

Germaine Bigot. . . . 14

Gismonda . ........16

Gloire de Charles Gombault. ......16

Grandiflora........19

James Kelway.....13

Japanese No. 3....26
Page

Japanese No. 5....26

Jeanne d'Arc. . . . . . 13

Jubilee . . . . . . . . . . 19

Judge Berry . . . . . . 21

KarI Rosefield . . . . 18

Kelway's Glorious. . 21

La France. . . . . . . 21

La Rosiere......... . 14

Lady A I e x a n d r a

Duff...........20

Lamartine........ 18

Laura Dessert......22

Le Cygne......... . 22

Livingstone. . . . . . . 16

Longfellow ........ . 22

Lora Dexheimer... . 18

Louise Renault..... . 14

Madame B a ri I le t

Deschamps.....13

Madame Calot..... 13

Madame de Galhau.14

Madame de Verneville............13

Madame Ducel.....14

$\mathrm{M}$ a d a m e Emile Galle.......... . . 14

Madame Emile Lemoine......... 14

Madame Forel. . . . . 14

Madame Gaudichau.22

Madame Geissler... 14

Madame Jules Dessert..........22

Madame Lemonier. 16

Marechal Vaillant. .13

Marguerite Gerard. .16

Marie Crousse. ..... 18

Marie Jacquin . . . . . 18

Marie Lemoine. . . . . 18

Martha Bulloch.... 22

Mikado.........26

Milton Hill. . . . . . . 22

Mireille.......... 14
Page

Modele de Perfection.........13

Modeste Guerin. . . . 15

Mons. Dupont. . . . . 13

Mons. Jules Elie . . . 18

Mons. Martin Cahuzac.......22

Nymphaea.......23

Octavie Demay . . . . 13

Officinalis $\mathrm{R}$ o s e a Plena..........27

Officinalis Rubra

Plena.........27

Pasteur.......... 18

Petite Renee....... 16

Philippe Rivoire... . 23

Philomele.........15

Phøebe Cary ....... 23

Pierre Duchartre... 20

Pierre Reignoux... . 19

Primevere... . . . . . 24

Princess Mathilde. 26

RaouI Dessert. . . . . 24

Reine Hortense . . . 19

Richard Carvel.....24

Rosa Bonheur......24

Rosy Dawn.......26

Rubra Superba..... 16

Sarah Bernhardt. . 20

Solange.........25

Solfatare..........13

Souv. de I'Exposi-

tion Universelle. . 15

Souv. de Louis Bigot25

Suzanne Dessert. . . 16

The Moor........27

Therese........25

Tourangelle.......25

Triomphe de I'Ex-

position de Lille..15

Umbellata Rosea...13

Venus.............19

Victoire de Ia Marne.25

Victoria.........27

Walter Faxon......25 


\section{Read Carefully Before Ordering}

This catalog is issued annually on or about August 1, and prices quoted hold good only for current year of publication.

Why You Should Order Early. Many Peonies in the better grades are in limited supply and are oversold yearly. The propagation of the Peony is slow, and we do not "make" varieties to order.

Shipping season begins about the middle of September and ends with the freezing up of the ground. We do not ship Peony roots in the spring.

\section{SPECIAL ANNOUNCEMENT}

\section{Peony Shipping Season}

Transportation charges will be prepaid on all retail Peony orders paid for in advance that are to be shipped east of the Mississippi.

To obtain prepaid shipment west of the Mississippi, the order must amount to $\$ 10.00$ or more, paid in advance.

We will ship either by Express or Parcel Post, depending upon the size of the order. If your Express Office is different from your Post Office, please state this on the order sheet.

Safe arrival of roots in good condition is guaranteed.

Remittances may be made by Bank Draft, Express or Post Office Money Order on Fair Lawn, N. J., Check, or Currency in Registered Letter, same to accompany order.

Charge Accounts. We are pleased to open a charge account if desired. Kindly tell us just a little about yourself or mention friends of yours who have dealt with us. It is advisable to furnish your bank reference. No account opened for less than $\$ 10.00$.

C. O. D. Orders must be accompanied by a deposit of about 25 per cent of the value of roots ordered.

We do not solicit orders under $\$ 2.00$. 

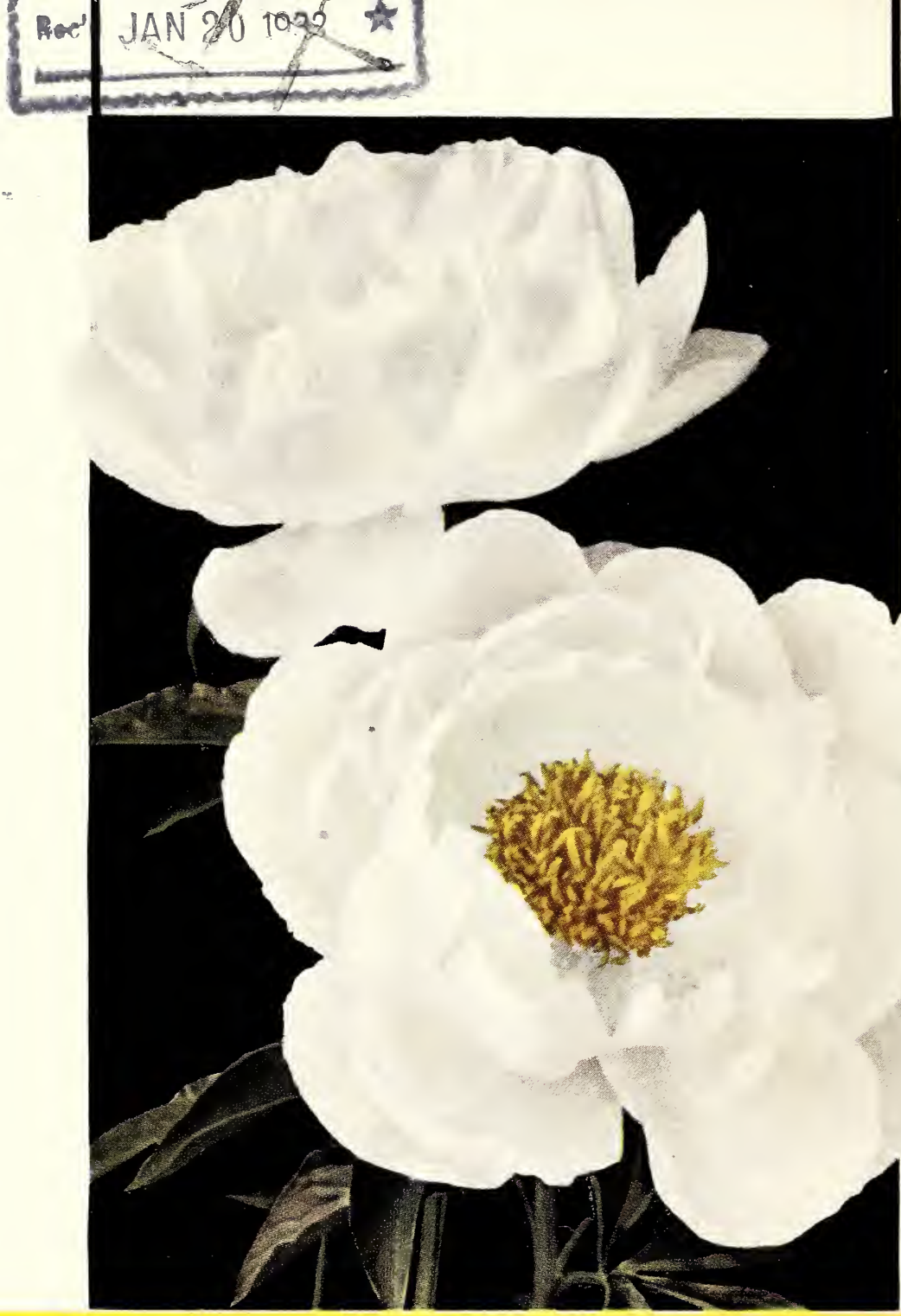

\section{GEORGE H. PETERSON I NCORPORATED \\ Rose and Peony Specialists Fair Lawn, NewJersey}

